\title{
Comparison of 20th century and pre-industrial climate over South America in regional model simulations
}

\author{
S. Wagner ${ }^{1}$, I. Fast ${ }^{2}$, and F. Kaspar ${ }^{3}$ \\ ${ }^{1}$ Helmholtz-Zentrum Geesthacht, Geesthacht, Germany \\ ${ }^{2}$ German Climate Computing Center - DKRZ, Hamburg, Germany \\ ${ }^{3}$ Deutscher Wetterdienst - DWD, Offenbach, Germany
}

Correspondence to: S. Wagner (sebastian.wagner@hzg.de)

Received: 1 September 2011 - Published in Clim. Past Discuss.: 22 September 2011

Revised: 27 August 2012 - Accepted: 10 September 2012 - Published: 16 October 2012

\begin{abstract}
In this study, we assess how the anthropogenically induced increase in greenhouse gas concentrations affects the climate of central and southern South America. We utilise two regional climate simulations for present day (PD) and pre-industrial (PI) times. These simulations are compared to historical reconstructions in order to investigate the driving processes responsible for climatic changes between the different periods. The regional climate model is validated against observations for both re-analysis data and GCM-driven regional simulations for the second half of the 20th century. Model biases are also taken into account for the interpretation of the model results. The added value of the regional simulation over global-scale modelling relates to a better representation of hydrological processes that are particularly evident in the proximity of the Andes Mountains.

Climatic differences between the simulated PD minus PI period agree qualitatively well with proxy-based temperature reconstructions, albeit the regional model overestimates the amplitude of the temperature increase. For precipitation the most important changes between the PD and PI simulation relate to a dipole pattern along the Andes Mountains with increased precipitation over the southern parts and reduced precipitation over the central parts. Here only a few regions show robust similarity with studies based on empirical evidence. However, from a dynamical point-of-view, atmospheric circulation changes related to an increase in high-latitude zonal wind speed simulated by the regional climate model are consistent with numerical modelling studies addressing changes in greenhouse gas concentrations.

Our results indicate that besides the direct effect of greenhouse gas changes, large-scale changes in atmospheric cir-
\end{abstract}

culation and sea surface temperatures also exert an influence on temperature and precipitation changes in southern South America. These combined changes in turn affect the relationship between climate and atmospheric circulation between PD and PI times and should be considered for the statistical reconstruction of climate indices calibrated within presentday climate data.

\section{Introduction}

The climate of South America is influenced by the interplay of different large-scale atmospheric and oceanic phenomena and topographic features of the continent. In the tropical and subtropical regions the climate is influenced by the presence of the South American Monsoon System (SAMS). The SAMS represents a continent-ocean circulation with ascending air masses over the continent and descending air masses over the oceans.

The atmospheric circulation is also influenced by surface topography and land-atmosphere interactions and specific topographical conditions over tropical South America such as the Brazilian highlands topography (cf. Vera et al., 2006a). The SAMS shows a pronounced seasonality with a rainy season starting in September. Another important feature of the SAMS relates to the South Atlantic Convergency Zone (SACZ), a region with increased cloudiness and associated precipitation, extending from southern Amazonia into southeastern Brazil and the adjacent oceanic regions (Carvalho et al., 2004; Vera et al., 2006a). The specific land-sea configuration and the presence of the Andes Mountains also provoke 
the formation of the South American Low Level Jet (SALLJ). The mechanisms leading to the formation of the SALLJ are related to a number of processes ranging from a deflection of the trade winds over the Amazonian basin, topographically induced processes, changes in the position of circulation centers over southern South America or the intrusion of low-level wind bursts from the Atlantic Ocean over the Amazonian basin into the La Plata basin (Vera et al., 2006b). A second aspect indirectly connected with the SALLJ relates to the establishment of meso-scale circulation features, the Chaco low in the lower tropospheric levels and the Bolivian High as its mid- and upper tropospheric counterpart. These circulation features related to the SAMS, SACS, the Bolivian high and Chaco low show a strong seasonal component and are important features of the warm and rainy season from September to March over the tropical and eastern parts of the subtropical regions.

The mid-latitudes and regions further south are dominated by the southern hemispheric westerly winds. Due to the complex structure of the southern hemispheric westerly winds, the westerlies can be differentiated into different latitudinal and vertical sections. The study of Bals-Elsholz et al. (2001) points to the split-up of the southern hemispheric jet streams into different branches within different seasons. During winter and spring the jet stream breaks up into subtropical and subpolar jet streams over the South Pacific in the upper tropospheric levels, whereas during summer and autumn only the subtropical jet is established.

Nakamura et al. (2008) highlight the importance of SST gradients for the intensification of the polar front jet and the strength of the Antarctic Oscillation (AAO)/Southern Annular Mode (SAM), mostly pronounced during austral winter. The SAM is the most dominant pattern of atmospheric circulation variability in the Southern Hemisphere and represents, depending on the season, up to $30 \%$ of the total SLP or geopotential height variance (Thompson and Wallace, 2000). In its positive phase, the westerly winds are intensified over the mid- and high latitude Southern Hemisphere. In the 2nd half of the 20th century the SAM showed a trend towards its positive phase (Thompson et al., 2000). This positive trend has been shown to be related to anthropogenic greenhouse gas emissions and the stratospheric ozone depletion (cf. Marshall et al., 2004; Cai and Cowan, 2007). Cai and Cowan (2007) conclude that the trend in the SAM is only half when ozone depletion is neglected. A more recent study by Wilmes et al. (2012) based on the analysis of the output of externally forced (solar, volcanic, greenhouse gases) GCM simulations of the period 1500-2000 AD shows a shift of the SAM to its positive state in 20th century. The simulations indicate that regional temperatures over the Southern Hemisphere are influenced by changes in greenhouse gases and volcanic eruptions, whereas precipitation shows no response to changes in external forcings. Authors also state that their results for temperatures are different to proxy data, the lat- ter suggesting that internal variability rather than changes in external forcings control temperature variability.

Another climatic aspect influencing the climate of South America is sea surface temperatures (SST; cf. Lamy et al., 2010; Seager et al., 2010). Especially over the mid- and high latitudes, SST variability is found to be related to changes in the SAM (Hall and Visbeck, 2002; Sen Gupta and England, 2006). Seager et al. (2010) emphasise in their study that $40 \%$ of the precipitation variability in south-eastern Brazil can be explained by SST variability. The authors argue that recent trends in precipitation were not influenced by anthropogenic greenhouse gas forcing, but rather by the natural mode of variability related to the Atlantic Multidecadal Oscillation. For the high latitudes over the southern ocean, processes related to Ekman pumping, i.e., wind-driven divergences in the upper ocean are an important climatic feature (Yang et al., 2007; Screen et al., 2010). This effect also has implications for climatic changes because the increased Ekman pumping could potentially dampen temperature increases induced by increased greenhouse gas concentrations.

In the present study, differences in the climate over central and southern South America between the second half of the 20th century and pre-industrial times will be investigated. We set out to test hypotheses whether changes related to a different content of greenhouse gases $\left(\mathrm{CO}_{2}\right)$ exert an influence on different climatic variables and which forcing mechanisms might drive climatic changes. Previous studies investigated the effects of changes in the greenhouse gas concentration on the climate of the Southern Hemisphere in the second half of the 20th century and for future climate simulations. The general pattern for the A1B scenario (the mean of the period 2080-2099 compared to the reference period 1980-1999) shows a temperature increase for southern South America in the range of 1.7 to $3.9 \mathrm{~K}$, mostly pronounced over the interior of the continent (Christensen et al., 2007). For precipitation the pattern is somewhat more heterogeneous. However, most models indicate a decrease in precipitation extending from central and northern Chile into northern Patagonia, whereas increases in precipitation are evident over the La Plata basin and southernmost Patagonia. Changes in greenhouse gas concentrations also influence changes in atmospheric circulation patterns (Christensen et al., 2007). These changes mainly relate to an intensification of the south-eastern Pacific and south-western Atlantic high pressure cells. This intensification and extension can also be linked to the decrease in precipitation in central and northern Chile and central Patagonia, while the increase in precipitation in southernmost Patagonia can be related to changes in the South Atlantic storm track. The precipitation increase over the La Platin basin is also related to the anomalous southeastward advection of humid air masses from the South Atlantic Ocean in conjunction with the intensification of South Atlantic high pressure cell.

A second issue addressed in this study is whether simulated changes with the regional model are consistent with 
climate reconstructions based on proxy data. Therefore, we will compare those proxy-based climate reconstructions with our regional climate model simulations. The general pattern of the pre-industrial (Little Ice Age, LIA) climate based on empirical evidence suggests cooler temperatures, albeit with decadal fluctuations (Villalba et al., 2003; von Gunten et al., 2009). Villalba et al. (2003) reconstructed temperatures across the southern Andes based on tree-ring data back to $1640 \mathrm{AD}$. The authors found that temperatures in the 20th century are approx. $0.5 \mathrm{~K}$ (northern parts) to $0.8 \mathrm{~K}$ (southern parts) higher compared to the period 1640-1899. This underpins the increased temperatures of the 20th century compared to pre-industrial times. The authors also point to the crucial role of changes in large-scale SSTs in the South Pacific and South Atlantic Ocean in controlling temperature changes. Even more important than for temperature is the high spatiotemporal variability of precipitation within the LIA, complicating the hydrological pattern for LIA conditions, as discussed by Meyer and Wagner (2009) for Patagonia. For instance, for south-eastern Patagonia $\left(52^{\circ} \mathrm{S}\right)$, wetter conditions are reconstructed based on higher lake levels (Mayr et al., 2005; Haberzettl et al., 2005). Wetter and cooler conditions are also supported by analysis based on glacial advances (Vimeux et al., 2009; Masikoas et al., 2009). In contrast, for the more northern regions around $30^{\circ} \mathrm{S}$ drier conditions have been reconstructed for the 17th and 18th century based on lake level fluctuations (Piovano et al., 2002) and tree-ring data (Boninsegna, 1995).

More quantitative approaches on the empirical side have recently been undertaken by Neukom et al. $(2010 a, b)$ amalgamating a huge number of different types of proxy data into climate field reconstructions. Neukom et al. (2010a) carried out a study reconstructing climatic variables (precipitation and near-surface temperatures) over central and southern South America based on a large number of proxy data incorporating tree rings, lake sediments, marine sediments, ice cores, corals and instrumental data. The authors use different statistical methods to reconstruct spatially resolved temperature fields for austral summer and winter back to 900 AD. Spatially averaged temperatures covering southern South America show a clear decline in the LIA and an increase in the course of the 20th century. The precipitation reconstruction carried out by Neukom et al. (2010b) also using a multi-proxy network similar to the one used for temperature reconstructions shows a more heterogeneous pattern and differences between different centuries are more complex in nature. However, some overarching issues are an increase in precipitation in the 20th century (1931-1990 AD) in southern Patagonia during austral summer and a decrease in precipitation over most regions of southern South America south of $20^{\circ} \mathrm{S}$ during austral winter, with the exception of regions to the northeast of $30^{\circ} \mathrm{S}$ where increases in precipitation are evident.

In the context of comparing modeling studies with empirical data, the exact definition of the westerly winds plays an important role. Therefore, it has to be clear whether upper or lower tropospheric winds are discussed. For most studies based on empirical data the definition most often relates to changes in low-level winds. This is because the near-surface winds directly influence regional and local environments and, therefore, this information will eventually be partly contained within the empirical evidence such as lake sediments (Markgraf et al., 2003; Haberzettl et al., 2005), marine sediments (Lamy et al., 2001, 2010) and pollen records (Schäbitz, 1999; Moreno et al., 2009). In this study, we will address this point by analysing different tropospheric levels in terms of maximum and mean zonal winds. This will facilitate the comparison with already existing and future studies carried out in the context of westerly winds in South America.

Concerning the relationship between circulation and precipitation, in the paper of Garreaud (2007) the relationship between zonal winds and precipitation is established for the observational periods. Specifically for the South American region high correlations are evident at the western side of the Andes Mountains, whereas regions to the east show negative correlations, especially for the correlation between the $850 \mathrm{hPa}$ zonal winds and precipitation. An important point mentioned by Garreaud (2007) relates to the relevance of the temporal scales the analysis between circulation and precipitation variability is based upon, for instance, related to the passage of cyclones over the Andes Mountains. Although these disturbances are short lived, they might be important for the generation of precipitation anomalies in eastern Patagonia that cannot be explained by analysis based on monthly mean values. However, even at monthly time-scales, precipitation events due to cyclones are still present, though it may not be possible to identify whether precipitation is due to cyclones or to the orographically induced rain shadow effect induced by the Andes Mountains.

A question regarding longer time scales in context of the paleo-perspective refers to the stationarity in the relationship between precipitation and zonal winds or the general relationship between climate and circulation. This questions, if the changes in the background climate, for instance, induced via changes in external forcing parameters, could alter the correlation/regression structure of the patterns or their amplitudes. This point will be investigated using the output of the regional climate simulations for present-day and preindustrial times. An important point that should be taken into account investigating the climate-circulation relationship relates to dynamical and physical reasoning underlying the relationship. This is important, especially when the linkage is not very large or when the relationship will be used for predictive purposes for past or future climates.

The paper is structured as follows: in the next section the global and regional climate models are introduced including the experimental setup. Section 3 includes the validation of the climate models for selected atmospheric variables in representing the annual cycle for single grid points and spatially 
resolved fields. In Sect. 4, we present the climatic differences between present-day and pre-industrial times. Then, forcing mechanisms for temperature and hydrological changes are discussed focusing on wind-induced versus non-wind induced changes. Section 5 includes a discussion of the results and the paper closes with the summary of the main findings in Sect. 6.

\section{Climate models and experimental setup}

The global model used for all experiments is the coupled atmosphere ocean general circulation model ECHO-G (Legutke and Voss, 1999; Min et al., 2005). The model consists of the atmospheric model ECHAM4 (Roeckner et al., 1996) coupled to the oceanic model HOPE-G (Wolff et al., 1997). The atmospheric component is a spectral model with a horizontal resolution of T30 (approx. $3.75^{\circ}$ lat $\times 3.75^{\circ}$ lon) and 19 vertical levels. The ocean model HOPE-G has 20 vertical levels and an effective horizontal resolution of approximately $2.8^{\circ}$ lat $\times 2.8^{\circ}$ lon with a gradual meridional refinement (reaching $0.5^{\circ}$ ) towards the equator in order to better represent ENSO-related processes.

For the regional simulations the climate model CCLM, the climate version of the non-hydrostatic limited-area operational weather prediction model of the Consortium on Small scale Modelling (COSMO), was used (Böhm et al., 2003; Rockel and Geyer, 2008). All simulations use the model version CCLM 4.2. The model is setup on rotated spherical coordinates with a resolution of $0.44^{\circ} \times 0.44^{\circ}$, corresponding to a horizontal grid point distance of approx. $50 \mathrm{~km} \times 50 \mathrm{~km}$. The geographical domain consists of $128 \times 103$ grid points in the latitudinal and longitudinal direction, respectively. The centre of the domain is located at $62.5^{\circ} \mathrm{W} ; 40^{\circ} \mathrm{S}$. For the analysis of model results the fields have been interpolated onto a regular geographical grid with a horizontal resolution of $50 \mathrm{~km} \times 50 \mathrm{~km}$, also allowing for better comparison with observationally based and gridded datasets.

In all, three simulations are investigated in this study: a simulation forced with the ERA40-reanalysis data (Uppala et al., 2005) for the period 1993-1997, and two simulations forced with the ECHO-G global model. The first simulation is driven with pre-industrial conditions representing external forcings of $1750 \mathrm{AD}(\mathrm{PI})$, the second one representing the present-day conditions of 1990 AD (PD). Both ECHO-G simulations are driven with constant external forcing conditions. The ERA40 driven CCLM simulation was carried out to test whether the regional climate model is able to reproduce basic climatic features of the South American climate. The length of the simulation of only five years was related to computational restrictions at the time when the simulations were carried out.

The regional simulations have been forced at the lateral boundaries with six-hourly data from the ECHO-G model. The lower boundary forcing was related to surface tempera- tures of the driving ECHO-G model. Each time slice experiment was carried out for $35 \mathrm{yr}$. For the purpose of analysis, the first five years have been neglected so as to allow the interior of the regional model fully adapt to changes in external conditions.

The $\mathrm{CO}_{2}$ concentrations were set to $330 \mathrm{ppm}$ for the PD simulation and to $280 \mathrm{ppm}$ for the pre-industrial PI simulation in the regional model. A difference between the driving ECHO-G model is the changed solar constant and the slightly increased $\mathrm{CO}_{2}$ concentrations - for the regional model, however, the solar constant remains the same in both simulations and differences in the regional simulation only relate to changes in $\mathrm{CO}_{2}$ concentrations. The historical increase in $\mathrm{CO}_{2}$ concentrations is from $280 \mathrm{ppm}$ in $1750 \mathrm{AD}$ over $295 \mathrm{ppm}$ in $1900 \mathrm{AD}$ up to $330 \mathrm{ppm}$ in the year $1975 \mathrm{AD}$. Accordingly, approximately $\frac{3}{4}$ of the increase in $\mathrm{CO}_{2}$ between PD and PI period happened during the 20th century. However, this transient increase was not taken into account in the regional simulations because they were carried out as time slice experiments using constant external forcing conditions during the integration. An overview of the settings of the forcings is given in Table 1.

All regional simulations were carried out with the same surface boundary forcing field, i.e., the land cover and vegetation is held constant throughout the simulation and is based on the ECOCLIMAP dataset (Masson et al., 2003). The soil conditions related to temperature and soil moisture are interactively simulated after initialisation from climatology. A more detailed description on the time invariant variables used in the CCLM model can be found in the study of Smiatek et al. (2008).

Figure 1 shows a comparison between topography in the driving ECHO-G GCM and the regional climate model CCLM. In the regional climate model CCLM the representation of regional topographic features is considerably improved. For example, the Andes Mountains can barely be distinguished in the ECHO-G model. Also their absolute height is very low compared to real world. The better representation of the complex topography, and also of the absolute heights, is a pre-requisite for a more realistic simulation of regional climatic processes.

\section{Validation of the regional model with observational datasets}

Model validation is a crucial point in regional climate modeling, because it is not a priori guaranteed that the increased resolution of the regional model compared to the global model produces better results.

The observational gridded datasets used for comparison are the data products of the Climate Research Unit (CRU, Mitchell and Jones, 2005) for temperature $\left(0.5^{\circ} \times 0.5^{\circ}\right.$ horizontal resolution), the "Global Precipitation Climatology Center (GPCC) Climatology Version 2010" for mean 
Table 1. Experiment setup for external forcing for the driving ECHO-G model and the regional climate model CCLM for the present day (PD) and pre-industrial period (PI). All simulations are carried out with constant forcing (quasi-equilibrium simulations).

\begin{tabular}{llllll}
\hline & \multicolumn{2}{c}{ ECHO-G } & & \multicolumn{2}{c}{ CCLM } \\
\cline { 2 - 3 } \cline { 5 - 6 } & PD & PI & & PD & PI \\
\hline $\mathrm{CO}_{2}[\mathrm{ppm}]$ & 350 & 280 & & 330 & 280 \\
Solar constant $\left[\mathrm{W} \mathrm{m}^{-2}\right]$ & 1367 & 1365 & & 1365 & 1365 \\
Orbital forcing & Present-day & Present-day & & Present-day & Present-day \\
Simulation period & 1990 AD 35 yr & 1750 AD 35 yr & & 1990 AD 35 yr & 1750 AD 35 yr \\
\hline
\end{tabular}
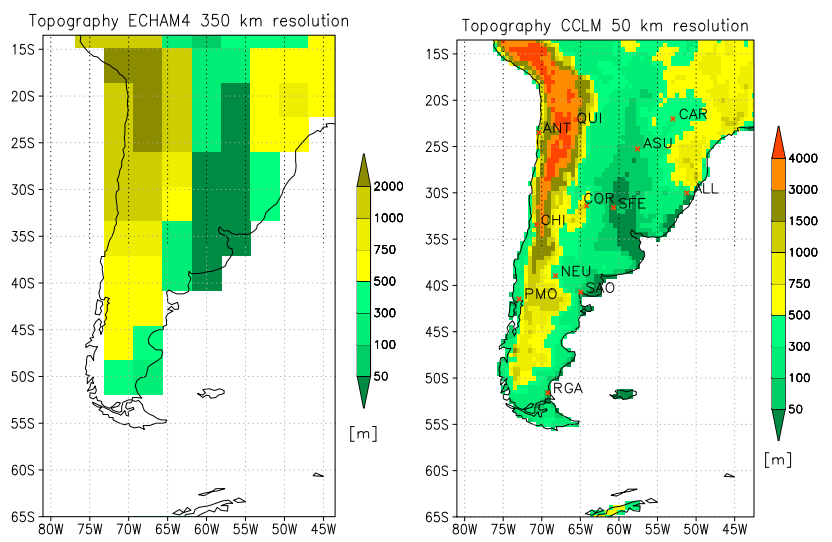

Fig. 1. Comparison between the resolution of the GCM ECHO-G $(350 \mathrm{~km})$ and CCLM $(50 \mathrm{~km})$. Note the considerable increased resolution of the regional climate model, most notably for the Andes Mountains. The grid points used for comparison are indicated in the right figure. The exact latitude and longitude information is included in Table 2.

monthly precipitation $\left(0.5^{\circ} \times 0.5^{\circ}\right.$ horizontal resolution $)$, the "GPCC Full Data Reanalysis Version 5" time series of monthly means (Rudolf et al., 2010), and the National Center for Environmental Prediction and National Center for Atmospheric Research (NCEP/NCAR) re-analysis (Kistler et al., 2001) for sea-level pressure $\left(2.5^{\circ} \times 2.5^{\circ}\right.$ horizontal resolution. For the validation a five year (1993-1997) long CCLM simulation forced with data from the European Center for Medium Weather Forecast (ECMWF) 40 Year Re-analysis Project (ERA-40) was carried out (cf. Uppala et al., 2005).

Grid points co-located with a meteorological station that are entering the gridded observational data (CRU or GPCC) set within the respective region were selected from the output of the regional climate model and then compared with a grid point from the gridded observational dataset. The rationale is that due to the high spatial variability for precipitation, the comparison of areal averages might be flawed by the sparseness of observational data. The spatially resolved validation will be presented in Sect. 3.2, also including a comparison between the ECHO-G + CCLM simulation and the raw ECHO-G output for the 2nd half of the 20th century.
Table 2. Locations used for the comparison between the ERA40 + CCLM simulation and observations. The stations are entering the gridded observational products used for comparison (CRU and GPCC).

\begin{tabular}{lll}
\hline Station & lat & lon \\
\hline Sao Carlos & $22^{\circ} 01^{\prime} \mathrm{S}$ & $53^{\circ} 00^{\prime} \mathrm{W}$ \\
La Quiaca & $22^{\circ} 07^{\prime} \mathrm{S}$ & $65^{\circ} 36^{\prime} \mathrm{W}$ \\
Antofagasta & $23^{\circ} 29^{\prime} \mathrm{S}$ & $70^{\circ} 24^{\prime} \mathrm{W}$ \\
Asuncion & $25^{\circ} 16^{\prime} \mathrm{S}$ & $57^{\circ} 40^{\prime} \mathrm{W}$ \\
Porto Allegre & $30^{\circ} 02^{\prime} \mathrm{S}$ & $51^{\circ} 12^{\prime} \mathrm{W}$ \\
Cordoba & $31^{\circ} 24^{\prime} \mathrm{S}$ & $64^{\circ} 11^{\prime} \mathrm{W}$ \\
Santa Fe & $31^{\circ} 38^{\prime} \mathrm{S}$ & $60^{\circ} 42^{\prime} \mathrm{W}$ \\
Santiago de Chile & $33^{\circ} 27^{\prime} \mathrm{S}$ & $70^{\circ} 40^{\prime} \mathrm{W}$ \\
Neuquen & $38^{\circ} 57^{\prime} \mathrm{S}$ & $68^{\circ} 14^{\prime} \mathrm{W}$ \\
San Antonino Oueste & $40^{\circ} 44^{\prime} \mathrm{S}$ & $64^{\circ} 57^{\prime} \mathrm{W}$ \\
Puerto Montt & $41^{\circ} 28^{\prime} \mathrm{S}$ & $72^{\circ} 56^{\prime} \mathrm{W}$ \\
Rio Gallegos & $51^{\circ} 37^{\prime} \mathrm{S}$ & $69^{\circ} 13^{\prime} \mathrm{W}$ \\
\hline
\end{tabular}

\subsection{Validation based on single grid points}

Figure $2 \mathrm{a}$ and $\mathrm{b}$ show the annual cycle for near-surface temperatures and precipitation for selected grid-points in central and southern South America. The selection of the grid-point is based on the rationale that most climatic zones over central and southern South America are included in the comparison. An overview of the location of the grid-points co-located with meteorological stations is given in Table 2, the locations are also indicated in Fig. 1. It should be noted that single grid-points cannot represent entire climatic zones of South America because of their limited spatial representativeness. In addition to the gridded observational data, also grid points from the driving ERA40 re-analysis are included for comparison. It should be noted that the driving ERA40 data assimilate observational information and, therefore, even so the spatial resolution of the regional model might be higher compared to re-analysis, the re-analysis data compare better to observations than the regional model. An important point is that the CCLM model is only driven at its boundaries by the re-analysis data and, therefore, can freely evolve within its interior.

For temperatures, the basic structure of the annual cycle is captured by the CCLM model, albeit most grid-points show 

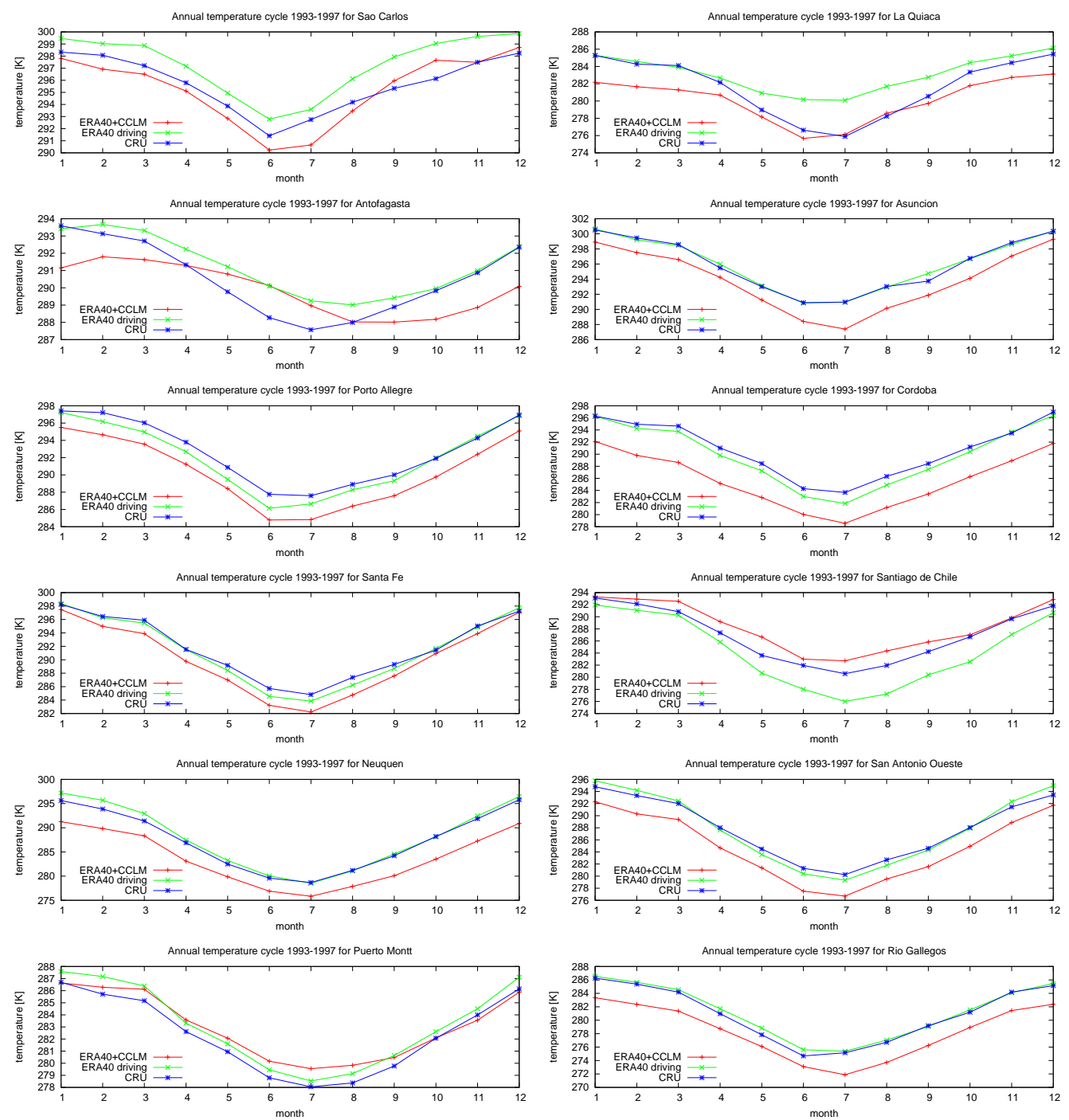

Fig. 2a. Model validation for the annual temperature cycle for the period 1993-1997 for grid points closest to a meteorological observation station entering the gridded product used for comparison. Red line: ERA40 + CCLM regional model output, green line: driving ERA40 re-analysis data used to drive the regional model, blue line: gridded CRU data based on observations.

a cold bias. The only exceptions are Antofagasta during austral winter and the grid point of Puerto Montt from January to September, indicating an overestimation of mean temperatures and a shift within the seasonal cycle. For Antofagasta the annual cycle is, however, completely shifted. The origin of the cold bias and the seasonal shift are unclear. The cold bias of the CCLM model (version 4.0) is also evident for other regions, for example the European continent (Jaeger et al., 2008). The respective reasons for the different cold biases might, however, be due to different causes and deeper analysis might be important to investigate the underlying mechanisms.

The precipitation cycle for the different stations is reproduced reasonably well by the CCLM, although the model shows some biases. For the northern grid points, the rainy season shows an underestimation for Sao Carlos and an overestimation for La Quiaca. Antofagasta in the dry Atacama Desert shows zero precipitation for the CCLM model throughout the year and in general less than $1 \mathrm{~mm}$ for the GPCC dataset, indicating that the model captures this regional climatic peculiarity reasonably well. For grid points located further south, CCLM also reproduces the annual cycle fairly well, albeit with some structural biases, for instance, related to an underestimation for Porto Allegre or an overestimation for Neuquen and Rio Gallegos. The general pattern indicates, however, that the CCLM model underestimates precipitation for more northerly grid points, whereas the southern grid points show an overestimation by the model. 

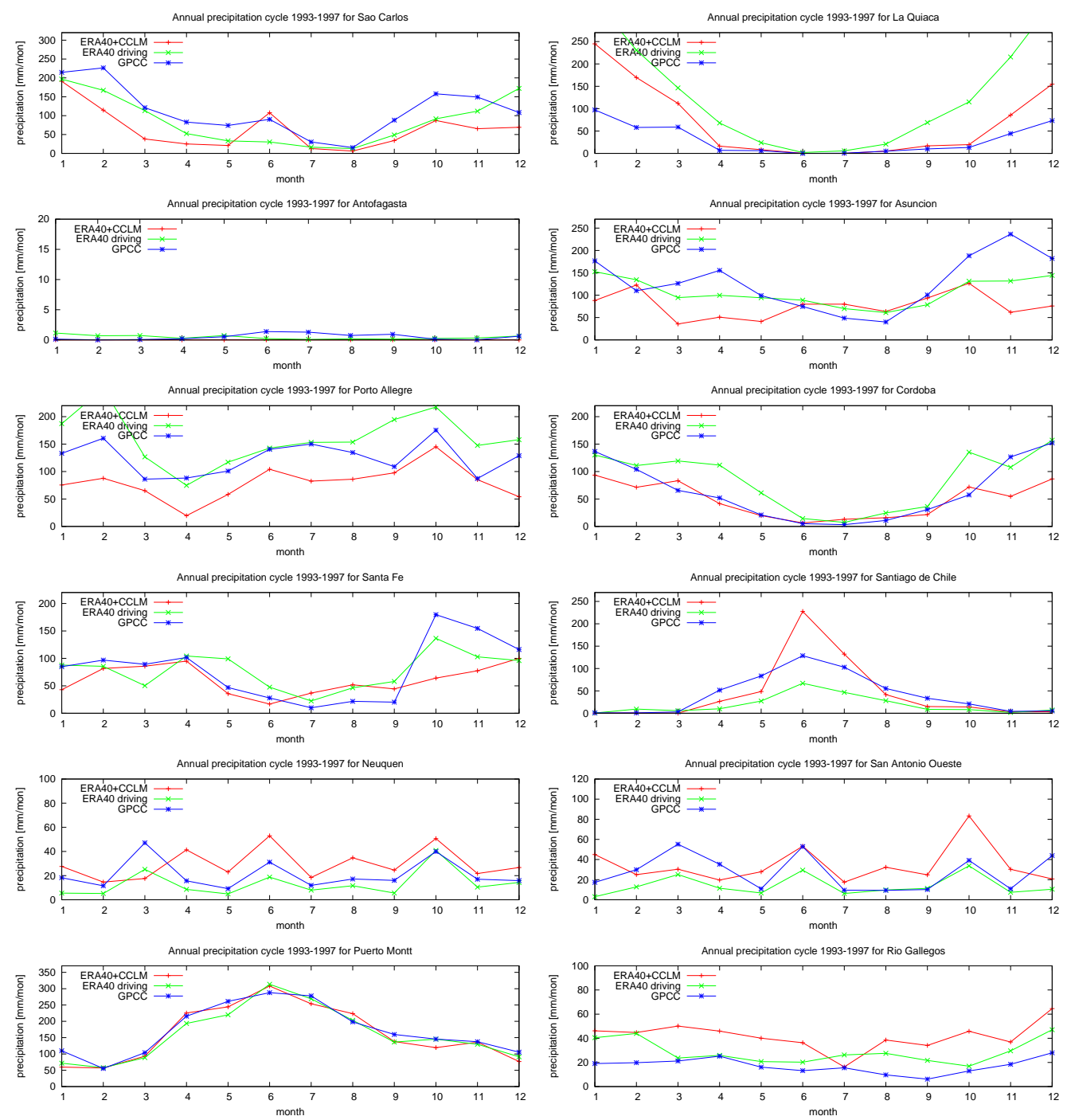

Fig. 2b. Same as Fig. 2a except for the annual precipitation cycle. Red line: ERA40 + CCLM, green line: driving ERA40 re-analysis data, blue line: gridded GPCC dataset based on observations.

The differences between the observations and the ERA40 + CCLM simulation are not explored in greater detail, but reasons potentially explaining the differences might be related to parameterisation of precipitation, small-scale land cover and soil property characteristics (cf. study of Anders and Rockel, 2009). Another very crucial point relates to the high complexity of the terrain. From the European Alps it is known that precipitation amounts can vary by a factor of two between stations located in the valley compared to high elevated stations. This point is very important because in southern South America no summit stations are available for the Andes Mountains. Neglecting this effect would potentially lead to a false interpretation of results obtained by the climate model simulation. This point was emphasised by Solman et al. (2008), stating that differences in mountainous regions between their MM5 simulations and other gridded reanalysis data products can be larger than $80 \%$. Silvestri et al. (2009) underscore that also differences between station heights and the mean height of model grid boxes complicate the comparison between observations and results from the regional climate model. In general, the authors state that the regional model considerably improves atmospheric circulation related to the summer monsoon circulation, the Bolivian High and the related subtropical jet. Also the precipitation cycle is represented reasonably well, albeit with overestimations in tropical and subtropical regions. For temperature the bias is below $1.5 \mathrm{~K}$. The authors conclude that the REMO regional model improves the global reanalysis data specifically for temperature in the tropical regions during the warm season and for precipitation in the subtropics and extratropical regions. 


\subsection{Validation based on spatially gridded fields}

Figures 3 to 5 contain results for the validation for spatially resolved fields of the different simulations used in the study. In addition to the ERA40 + CCLM simulation for the period 1993-1997 results for the CCLM simulation and the driving ECHO-G simulation for the late 20th century are given. For the latter, $31 \mathrm{yr}$ averages for the period 1960-1990 for the different observational datasets were used together with output for $31 \mathrm{yr}$ of the regional (ECHO-G + CCLM) and global (ECHO-G) climate model, as a basis for comparison.

An important difference to the ERA40-reanalysis data is that the ECHO-G simulation was not forced with observational data. The ECHO-G simulations were driven with constant external forcing conditions of $1990 \mathrm{AD}$. Therefore, the comparison of the ECHO-G ( + CCLM) simulation with observational gridded datasets for the period 1960-1990 is related to disentangle the major differences between models and observations for present-day climatic conditions.

The mean temperature fields of the ERA40 + CCLM simulation for the period 1993-1997 are displayed in the left column of Fig. 3. The simulation reproduces reasonably well the basic climatological features of the temperature field for central and southern South America. Differences between the ERA40 + CCLM simulation and CRU temperatures (2nd column) show mainly a cold bias over most regions, except for an overestimation along the coast of western South America. Differences between the ECHO-G + CCLM simulation (3rd column) as well as the driving ECHO-G simulation (4th column) deviate from the ERA40 + CCLM simulation showing positive temperature biases in most regions. These are mostly pronounced over the Andes Mountains in the central and Northern parts and the La-Plata basin in the ECHO-G model. However, the temperature bias in the ECHO-G model over the Andes Mountains is considerably reduced in the ECHO-G + CCLM simulation due to the higher elevated topography of the Andes Mountains in the regional simulation, reducing mean temperature levels over these regions.

The precipitation fields are displayed in Fig. 4. The left column shows the mean climatic conditions for the ERA40 + CCLM simulation. Precipitation differences between the ERA40 + CCLM simulation and the GPCC dataset show an underestimation over southeastern Brazil by the regional model, mostly pronounced during austral summer. It should, however, be noted that the ERA40 re-analysis data also show an overestimation of precipitation in the tropics (cf. Uppala et al., 2005). Another region showing prominent differences is located in the southern parts of the Andes Mountains related to an overestimation of the model precipitation compared to the GPCC data. However, the regional model shows a clear zone of increased precipitation that is not evident in the ECHO-G simulation. Even though the regional model overestimates precipitation, the windward effect induced by the Andes Mountains on precipitation is better visible in the regional model. A reason potentially explaining the overestimation of precipitation between the ECHO-G + CCLM simulation and the GPCC dataset might also be related to the sparseness of observations in these regions. The map presented in the study of Villa-Martinez and Moreno (2007) shows yearly precipitation sums up to $7000 \mathrm{~mm}$ along the southern Andes Mountains showing that the overestimation by the regional model might be related also to other than model deficiencies. The underestimation of precipitation in southeastern Brazil and the La-Plata region might be caused by too high sea-level pressure, preventing the generation of precipitation is this region (cf. Vera et al., 2006c).

The mean sea-level pressure fields of the ERA $40+$ CCLM simulation are displayed in the left column of Fig. 5. Pressure differences between the ERA40 + CCLM simulations and the NCEP/NCAR reanalysis (2nd column of Fig. 5) show a very similar pattern in all seasons. This relates to the overestimation of the pressure over south-east Brazil and Patagonia. The differences for the ECHO-G + CCLM are similar to results obtained for the ERA40 + CCLM simulation with pressure over eastern South America that is too high in all seasons. This positive pressure bias is also reported by Solman et al. (2008) for the MM5 model. A mechanism possibly influencing this bias might be an underestimation of Antarctic cold outbreaks generating mesoscale circulation features related to Chaco lows. Although these low pressure systems are not very long lasting, they account for a huge amount of precipitation generated in northeastern Argentina (cf. Salio et al., 2002). For the ECHO-G model, however, no in-depth analysis has been carried out and, therefore, part of this discrepancy might also be due to other reasons.

Over the high southern latitudes the ECHO-G + CCLM and the driving ECHO-G simulation show pronounced negative pressure differences in the southwestern parts, especially during austral winter. In conjunction with the positive pressure bias over the subtropical parts, this leads to an increased westerly flow over southern South America compared to the reanalysis data. This increased flow might also explain part of the overestimation of precipitation along the western slope of Andes Mountains. Another difference of the ECHO-G model relates to the underestimation of pressure over the Altiplano, mostly pronounced during austral summer that is again caused by the lack of a detailed topography in the GCM. The effect of the overestimation of the zonal circulation in the ECHO-G and ECHO-G + CCLM could also have further implications on the climate-circulation relationship that will be discussed in greater detail within the results section. 

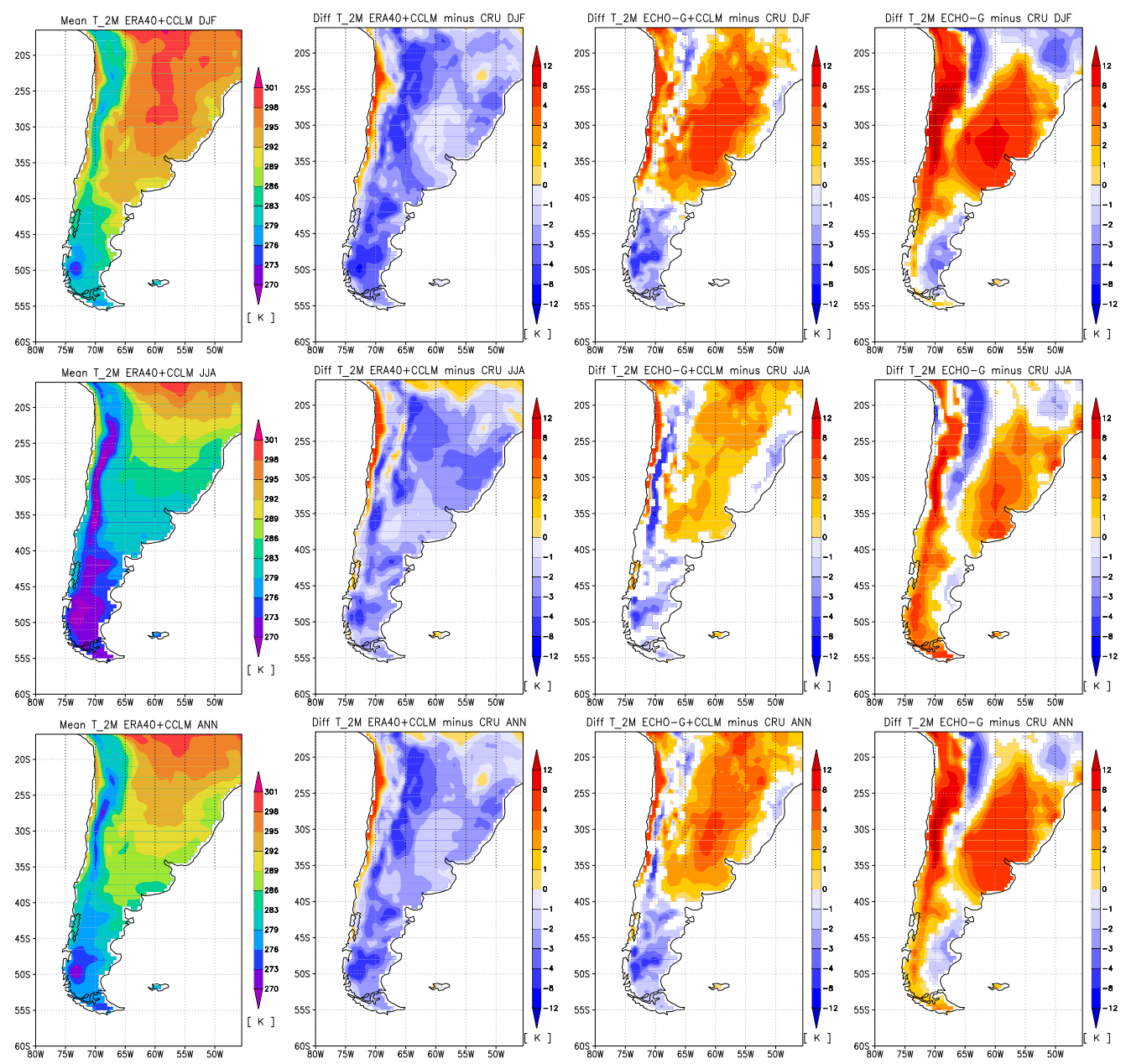

Fig. 3. Temperature fields for the different simulations. The left column shows the mean of the ERA40-CCLM simulation for DecemberFebruary (DJF, upper), June-August (middle) and the annual average (lower) for the period 1993-1997. The second column shows the differences to the CRU dataset for the same period. The 3rd and 4th columns show the differences of the ECHO-G + CCLM simulation and the ECHO-G simulation for present-day, respectively. For the ECHO-G (+ CCLM) simulation only values statistically significant different at the $5 \%$ level are displayed.

\section{Differences between the present-day and the pre-industrial climate}

\subsection{Near-surface temperatures, precipitation, sea-level pressure and sea surface temperatures}

In the following, differences between the present-day period representing conditions of the second half of the 20th century and the pre-industrial period representing conditions of $1750 \mathrm{AD}$ for selected atmospheric variables are presented. These variables include near-surface temperature, precipitation, sea-level pressure, zonal winds at $850 \mathrm{hPa}, 500 \mathrm{hPa}$, and $200 \mathrm{hPa}$ and changes in sea surface temperatures (SSTs). Changes in SSTs were not simulated by the regional climate model, instead they were used by the regional model as lower boundary condition. The difference between the present-day (PD) and pre-industrial (PI) regional simulation relates to the content of atmospheric greenhouse gases in terms of $\mathrm{CO}_{2}$ (i.e., $330 \mathrm{ppm}$ and $280 \mathrm{ppm}$, respectively).

Figure 6a shows the differences between the different variables for austral summer (December-February) and winter (June-August) and the annual mean, respectively. The temperature patterns (cf. left panel of Fig. 6a) mostly show higher temperatures during PD than PI over central and southern South America. Largest temperature differences are evident over the Andes Mountains, extending into the Pampas during austral summer. During austral winter a similar pattern is evident, albeit with highest temperatures during PD extending further equatorwards over the Andes Mountains and into the Amazonian basin. On the annual average, entire South America shows temperatures during PD that are increased in the order of $1.5 \mathrm{~K}$, over the Andes Mountains by $2.1 \mathrm{~K}$, compared to PI. 

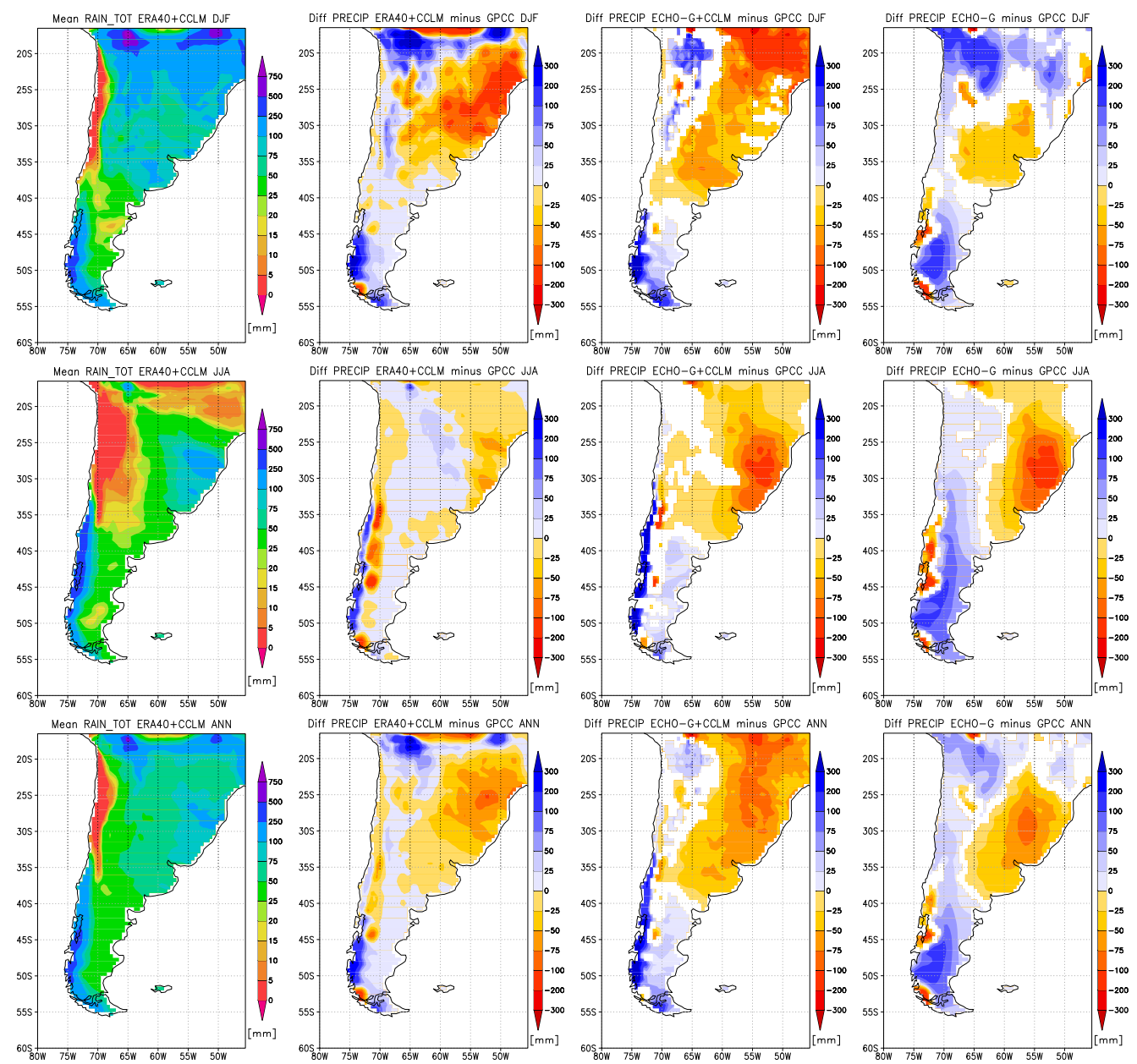

Fig. 4. Same as Fig. 3 except for precipitation based on the GPCC dataset.

Although SSTs are not simulated by the regional climate model their differences are displayed in Fig. 6b. Here the differences of the driving ECHO-G model are displayed for the different seasons. The regional domain has been extended to show the patterns also for regions further off the coasts of South America. Accordingly, the SST difference patterns between the PD and PI simulations also show significantly increased temperatures north of $55^{\circ} \mathrm{S}$, mostly pronounced over the South Atlantic Ocean to the east off the Argentinean coast. The pattern is also in congruence with a recent study by Wu et al. (2012), studying SST changes in western boundary currents in the 20th century. Specifically for South America the authors find a poleward extension of the Brazil current leading to an amplified warming in the region around $45^{\circ} \mathrm{S}$. A close inspection of the near-surface temperature difference maps shows that the increase in temperatures is not as large for regions showing non-significant SST differences compared to other regions located further to the north.

Precipitation differences (cf. middle panel of Fig. 6a) are more heterogeneous compared to near-surface temperatures for both magnitude and spatial variability. For example, wet- ter conditions during PD are evident over most of the Southern Ocean and the southern tip of South America. Over central South America the map only shows few regions with statistically significant differences in precipitation. A prominent feature pertains to changes along the Andes Mountains and Patagonia. During austral summer drier conditions during PD prevail over the southernmost regions. A latitudinal band separating the regions of wetter and drier conditions is located at approx. $50^{\circ} \mathrm{S}$. The drier conditions extend over the crest of the Andes Mountains into south-eastern Patagonia. For austral summer the pattern is similar to winter, albeit with a shift of the wetter conditions during PD over southern South America to the north around $45^{\circ} \mathrm{S}$. In contrast to austral summer, south-eastern Patagonia is characterised by increased precipitation during PD compared to PI. An important point is, therefore, the separate analysis of the different seasons to investigate changes in the seasonal precipitation cycle that would not be evident taking into account only annual mean changes (cf. also discussion in Wagner et al., 2007, for seasonal differences between the mid-Holocene and pre-industrial times). 

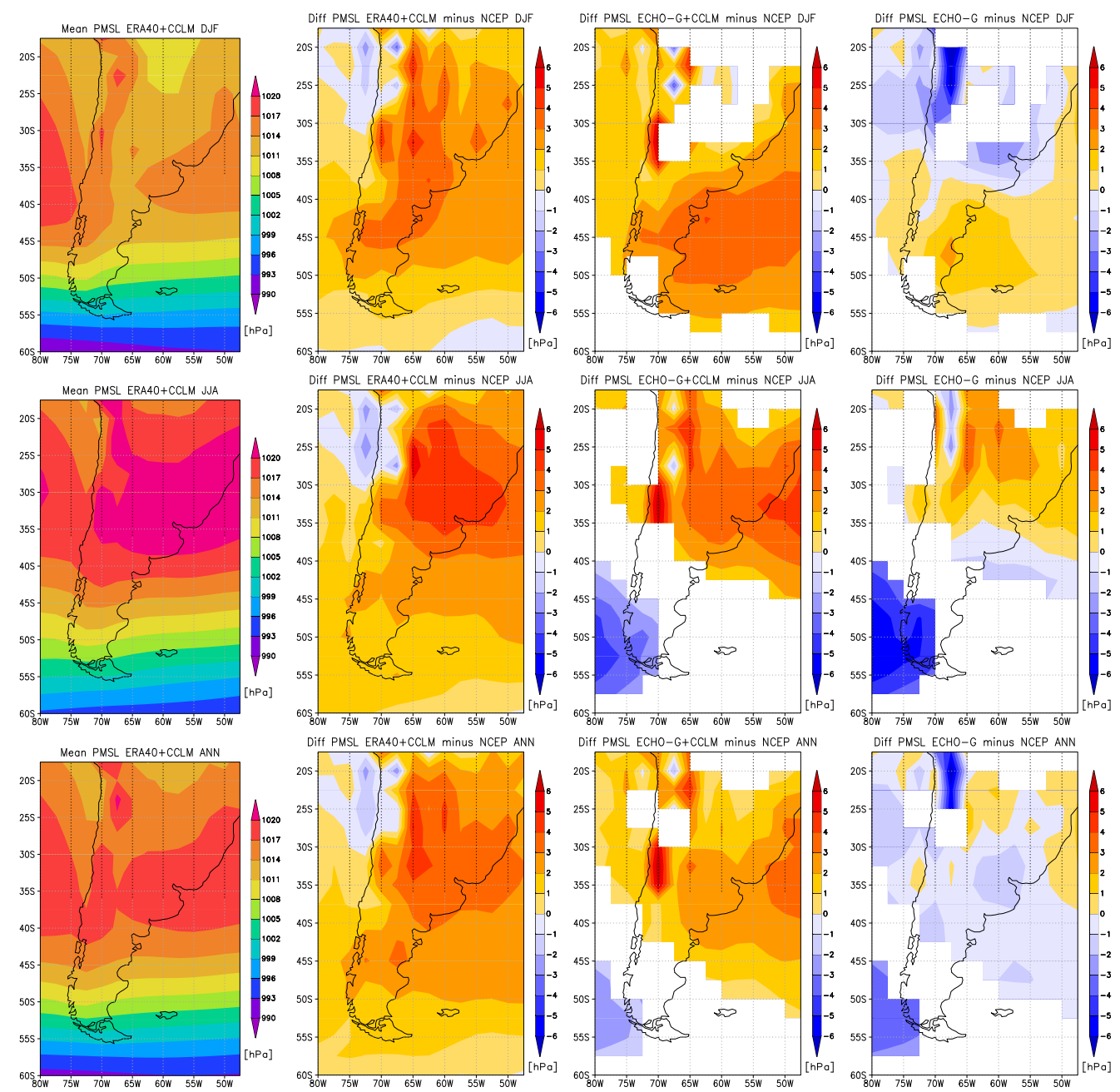

Fig. 5. same as Fig. 3 except for sea-level pressure. As reference the NCEP/NCAR dataset has been used.

The right panel of Fig. 6 shows changes in mean sea-level pressure between the PD and PI period. The basic pattern shows a dipole structure for both winter and summer season, with PD pressure decreases south of $55^{\circ} \mathrm{S}$ and increases to the North of $50^{\circ} \mathrm{S}$, mostly pronounced over the southwestern Atlantic Ocean. Also, over the central Andes Mountains and the Altiplano, pressure increases in the present-day climate. This pattern leads to an intensified westerly flow. Some regions showing an increase in sea-level pressure, for example south-eastern Patagonia during austral summer, also show a decrease in precipitation during PD. During austral winter the anomaly pressure pattern is slightly shifted towards the North. Moreover, the pattern shows a more non-zonal component compared to austral summer, leading to a more northwesterly flow. Similar difference patterns are also obtained when analysing the raw ECHO-G output for sea-level pressure. This similarity between regional and global model does, however, not disqualify the usage of the regional climate model because the added value of the regional model is mostly related to small-scale processes and variables related to the hydrological cycle, for instance precipitation and low-level winds over complex terrain.

\subsection{Comparison of model results with empirical data}

A difficulty in comparing the model results with empirical data is the fact that empirical reconstructions implicitly include varying external forcing factors. In the present model setup the simulations were forced with constant forcing for 35 (30) yr integration period (used for analysis). An implicit assumption underlying the following data-model comparison relates to the fact that different climatological background conditions in $1750 \mathrm{AD}$ vs. $1990 \mathrm{AD}$ should at least allow basic conclusions on the changes between pre-industrial and present-day climatic changes.

The modelled temperature changes presented in this study in the order of $1-2 \mathrm{~K}$ between present-day and preindustrial times overestimate the reconstructions by Neukom et al. (2010a) and Villalba et al. (2003) by approximately a 

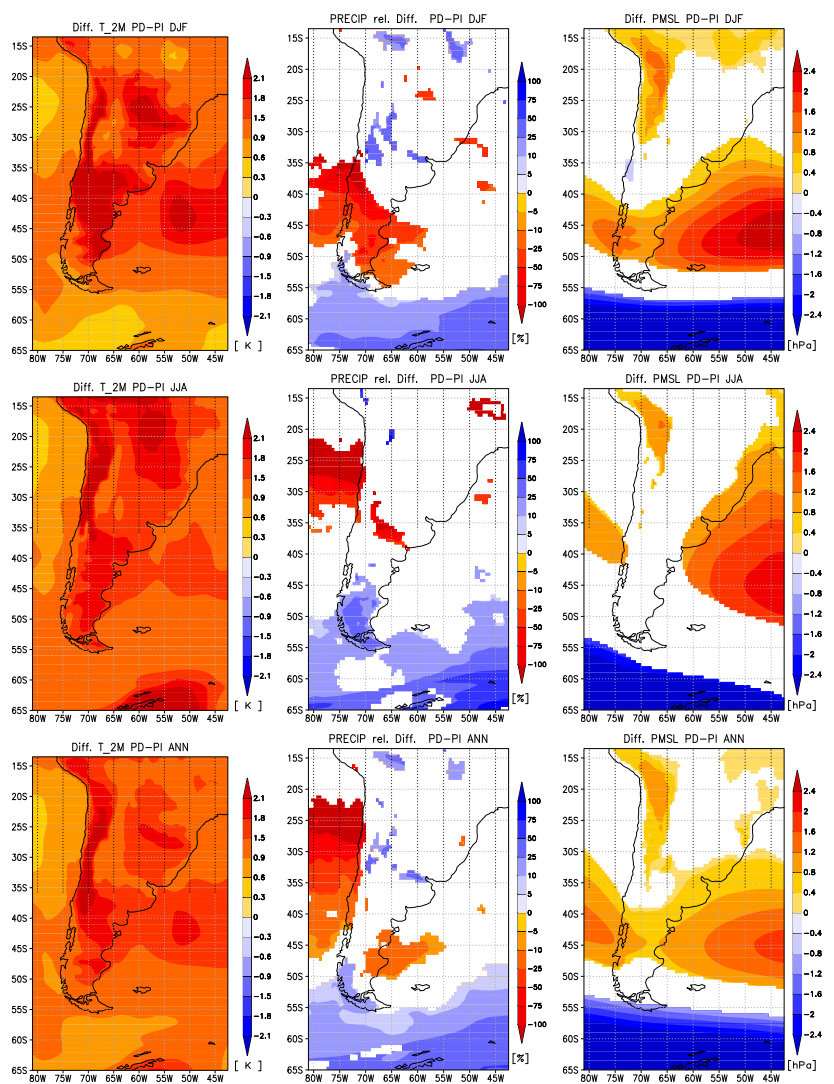

Fig. 6a. Difference maps between the present-day and the preindustrial periods for near-surface temperature (left column), precipitation (middle column) and sea-level pressure (right column). Results are displayed for austral summer (December-February, upper row), austral winter (June-August, middle row) and the annual mean (lower row). For precipitation relative changes (PD-PI)/PD are displayed. Only values statistically significantly different at the $5 \%$ level are given (two-sided t-test).

factor of two. For example, the study of Villalba et al. (2003) estimated temperature anomalies based on dendrochronological records for the period 1640-1899 AD for southern South America being approx. $0.9 \mathrm{~K}$ cooler compared to the 20th century. Summer temperatures for different southern South American regions shows similar levels in the late 20th century and the late 18th century, whereas in the 15th and 16th century temperatures were considerably lower compared to present-day (approx. $2 \mathrm{~K}$ for southern Patagonia). Winter temperatures show highest levels at the beginning of the 20th century followed by a slight decline (Fig. 6 of Neukom et al., 2010a). Lowest temperatures are reconstructed, however, for the 18 th century around $1750 \mathrm{AD}$. The latter is consistent with results of the regional simulation (cf. Fig. 6a). This result is also consistent with glacial advances in different regions of South America during this period as also stated by Koch and Killian (2005) for the Gran Campo Nevado in southernmost Chile and by von Gunten et al. (2009) based
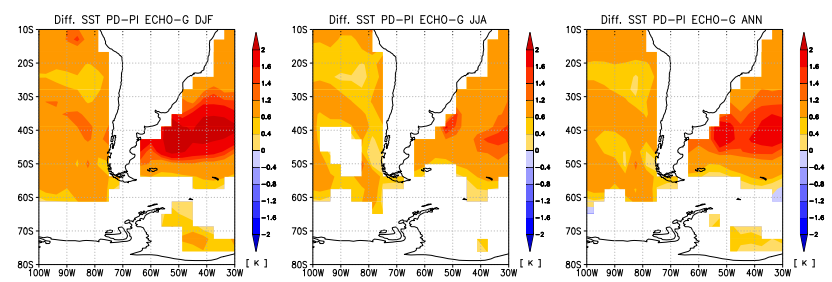

Fig. 6b. Difference maps between the present-day and the preindustrial periods for sea surface temperatures of the driving ECHO-G model. Left: DJF, middle: JJA, right: annual. Only values statistically significantly different at the $5 \%$ level are given (twosided t-test).

on a temperature reconstruction inferred from sedimentary pigments from Laguna Acuelo in Central Chile. The temperature reconstruction indicates a predominantly cool climate already starting in the 14th century and with a temperature reduction in summer temperatures in the order of $0.7 \mathrm{~K}$ to $0.9 \mathrm{~K}$ compared to the 20th century. For the Quelccaya ice cap Vimeux et al. (2009) report cooler and moister conditions over the high Andes Mountains in the period from 1600-1780 AD. The authors attribute these changed climatic conditions to an intensification of the South American Summer Monsoon related to changes in atmospheric circulation. Investigations carried out by Masiokas et al. (2009), for different regions in South America for glacier fluctuations over the last $1000 \mathrm{yr}$, indicate a general pattern of glacial retreat and ice loss for most regions of the Andes Mountains during the 20th century, being consistent with the modelled increase in temperatures between the period of LIA and the present day climate. However, it has also to be noted that glacier fluctuations in South America are not driven by temperature changes alone, but depending on the exact location of the glaciers are also influenced by the interplay of different climatic variables including precipitation and radiation variability (cf. Masiokas et al., 2009). A further study investigating climatological changes in southern South America of the last millennium relates to changes of the summertime Palmer Drought Severity Index (PDSI), carried out by Boucher et al. (2011). The authors point to the anti-phase relationship between Patagonia and the rest of southern South America.

The studies outlined above indicate that the pre-industrial period of the LIA is quite heterogeneous and, therefore, transient simulations including varying external forcings are needed to provide a better basis for comparisons. The general pattern of the PD-PI climatic changes indicates for the 18th century, the period where the regional simulations are centred that temperatures were predominately cooler. The cooler conditions are, thus, consistent with the findings based on the regional simulations also indicating lower temperatures during the PI period compared to the PD period.

Precipitation changes simulated by the model and reconstructed by Neukom et al. (2010b) deviate quite profoundly 
concerning the spatial extent and sign of positive and negative precipitation changes between the 20th century and the former centuries. The only region with similar changes in the model simulation and the reconstruction can be located over southern Patagonia during austral summer. The strong decrease in reconstructed precipitation over entire southern South America during austral winter is not reflected in the simulations. Instead, the model shows a dipole pattern with reduced precipitation in the northern and increased precipitation in the southern parts. This pattern also contradicts to the results of Boninsegna (1995) and Piovano et al. (2002), reporting drier conditions in central Chile for the 17th and 18th century around $30^{\circ} \mathrm{S}$. For south-eastern Patagonia the wetter conditions suggested by Mayr et al. (2005) and Haberzettl et al. (2005) are also only partly reflected in the regional simulations for austral winter. For the annual situation, no clear-cut changes are evident over this region. The study of Christie et al. (2010), investigating hydrological changes in Chile, starting in the mid 14th century is closer to the model results: the authors conclude that the 20th century shows an increase in extreme drought events, indicating drier conditions. They physically link the aridity changes to an increased westerly circulation related to the AAO/SAM during the summer half year caused by a poleward shift of the midlatitude stormtrack. The aridity is also reflected in the precipitation changes between the PD and PI simulation, especially in the regions of central and northern Chile.

\subsection{Changes in atmospheric circulation related to zonal winds}

In the present setup the question on changes in westerly winds can also be addressed using the output of the regional climate model. Table 3 shows changes in the intensity and latitudinal position of the maximum of zonal wind between the PD and the PI simulation for tropospheric levels at $200 \mathrm{hPa}, 500 \mathrm{hPa}$ and $850 \mathrm{hPa}$ for austral summer and winter together with the annual mean. The zonal wind of the different levels is related to the u-component of the wind field. For comparison, changes in the ECHO-G simulation without CCLM are given. This is to assess whether the regional simulation shows differences compared to the driving GCM.

According to Table 3, largest changes in maximum zonal wind speed are evident during austral summer. This can be seen especially for the poleward shift in the latitude of maximum wind speed. This poleward shift is also accompanied by an increase in maximum wind speed, especially at the $850 \mathrm{hPa}$ level. Differences between the regional and global model are also mostly pronounced at this level. Compared to austral summer, for austral winter only minor changes are evident. The regional model shows a slight poleward shift in conjunction with a slight increase in maximum wind speed. However, changes are too small to attain statistical significance at the $5 \%$ level. The annual mean also shows a poleward shift, mostly pronounced in the GCM. In the regional model a poleward shift is evident at the $500 \mathrm{hPa}$ and $850 \mathrm{hPa}$ level, the latter showing also statistically significant increases in maximum winds. The reasons for the southward shift are not clear. It might, however, be assumed that due to the better resolved topography in the regional model the maximum zonal winds are channelled and/or deflected, mostly pronounced within the lower atmospheric layers.

The analysis presented above addressed changes in the latitude and magnitude of the maximum of zonal wind. However, changes of maximum winds must not necessarily be related to changes in mean wind speed. Therefore, a spatially resolved analysis of mean zonal wind changes at different tropospheric levels is displayed in Fig. 7. For austral summer a dipole pattern with increased zonal winds south of $45^{\circ} \mathrm{S}$ and reduced winds north of $40^{\circ} \mathrm{S}$ is evident for all levels. During austral winter a similar pattern is evident, albeit weaker in amplitude. Only at the $200 \mathrm{hPa}$ level zonal winds show an increase in the northern parts of the domain. Unfortunately, the regional model does not show a clear-cut separation of the jet stream into a subtropical and a polar branch. This might be related to the fact that the driving GCM is too coarsely resolved and lacks of sufficient vertical level in order to account for a proper simulation of stratospheric processes including seasonal ozone variability. The annual mean patterns also show mainly a dipole pattern, mostly pronounced at the $850 \mathrm{hPa}$ level. At this level more local-scale structures are evident, for example along the Andes Mountains. Here the presence of spatially higher resolved topography in the regional model allows a better simulation of localscale features related to the local wind climate that are absent in the GCM. Thus, changes in mean zonal wind patterns reveals that increases in wind speed in a specific latitude are accompanied by a reduction in wind speed in another latitudinal band. This pattern is mostly evident during austral summer, indicating that the summer season reacts most sensitive to changes in atmospheric greenhouse gas concentrations, also in terms of zonal winds. The analysis further motivates a spatially resolved analysis, as the spatial patterns contain valuable information in addition to solely analysing changes in maximum wind speeds because also regions experiencing a reduction in zonal winds can be detected.

Results found for the GCM and the CCLM simulation are qualitatively in good agreement with other studies focusing on climatic changes caused by changes in greenhouse gas concentrations (Christensen et al., 2007). In this context, also the model bias induced by the driving ECHO-G model has to be considered, i.e., the overestimation in the high-latitude zonal circulation in the present-day simulation compared to re-analysis data (cf. Wagner et al., 2007). This point is also of importance for analysing the potential impact on changes in the climate-circulation relationship and their changes in time that will be elaborated in greater detail in the next section. 
Table 3. Mean position $\left({ }^{\circ} \mathrm{S}\right.$ ) (and intensity, $\mathrm{m} \mathrm{s}^{-1}$ ) of maximum zonal winds along $70^{\circ} \mathrm{W}$ for the pre-industrial (PI) and present-day (PD) simulation. The columns under ECHO-G display results for ECHO-G alone, the columns under ECHO-G + CCLM show results for the regional climate model simulation forced with ECHO-G. The difference to the pre-industrial simulation is given in parentheses. For the position, "-" indicates a more equatorward, "+" indicates a more poleward position during present-day period. The asterisk indicates values significantly different at the $5 \%$ level (two-sided test). DJF: December-February, JJA: June-August, ANN = annual mean.

\begin{tabular}{|c|c|c|c|c|}
\hline \multirow[b]{2}{*}{ DJF } & \multicolumn{2}{|r|}{ ECHO-G } & \multicolumn{2}{|c|}{ ECHO-G + CCLM } \\
\hline & PI & PD & PI & $\mathrm{PD}$ \\
\hline $\mathrm{U} 200$ & $42.0[36.9]$ & $45.2\left(+3.2^{*}\right)[36.5(-0.4)]$ & $40.9[36.8]$ & $43.7\left(+2.8^{*}\right)[36.4(-0.4)]$ \\
\hline U500 & 44.2 [19.9] & $47.5\left(+3.3^{*}\right)\left[20.6\left(+0.7^{*}\right)\right]$ & $43.0[20.2]$ & $45.9\left(+2.9^{*}\right)[20.2( \pm 0)]$ \\
\hline U850 & $49.3[11.8]$ & $51.6\left(+2.3^{*}\right)\left[13.3\left(+1.5^{*}\right)\right]$ & $46.4[13.7]$ & $49.6\left(+3.2^{*}\right)\left[14.6\left(+0.9^{*}\right)\right]$ \\
\hline \multicolumn{5}{|l|}{ JJA } \\
\hline U200 & $30.2[42.1]$ & $31.2(+1.0)\left[44.0\left(+1.9^{*}\right)\right]$ & $28.6[41.5]$ & $28.7(+0.1)[43.2(+1.7)]$ \\
\hline U500 & $39.0[21.2]$ & $38.1(-0.9)[21.6(+0.4)]$ & $35.7[23.9]$ & $36.3(+0.6)[24.0(+0.1)]$ \\
\hline $\mathrm{U} 850$ & $45.6[11.0]$ & $46.4(+0.8)[11.3(+0.3)]$ & $42.1[15.0]$ & $43.3(+1.2)[15.6(+0.6)]$ \\
\hline \multicolumn{5}{|l|}{ ANN } \\
\hline U200 & $38.7[34.7]$ & $38.3(-0.4)[35.4(+0.7)]$ & $38.7[34.2]$ & $38.2(-0.5)[34.6(+0.2)]$ \\
\hline U500 & $41.8[18.3]$ & $44.3\left(+2.5^{*}\right)[18.6(+0.3)]$ & $40.4[19.3]$ & $42.6\left(+2.2^{*}\right)[19.4(+0.1)]$ \\
\hline U850 & $47.3[10.0]$ & $50.0\left(+2.7^{*}\right)\left[11.2\left(+1.2^{*}\right)\right]$ & $44.6[12.9]$ & $45.7\left(+1.1^{*}\right)\left[13.5\left(+0.6^{*}\right)\right]$ \\
\hline
\end{tabular}

\subsection{Climate-zonal wind relationship in PI and PD climate}

In the following section, the relationship between changes in near-surface zonal winds and temperature and precipitation will be elaborated in greater detail. Special emphasis will be given to separate wind-driven versus non-wind-driven changes, the latter being caused by direct radiative forcing due to changes in greenhouse gas concentrations. This is important so as to differentiate the dominant processes controlling temperature and precipitation changes presented in the previous section. It should, however, be noted that a clear separation between only wind-driven and non-wind-driven effects on climatic changes is hampered by the fact that the windfield itself is influenced by changes in the external forcings. Thus, only parts of the climatic changes can be explained by wind-driven changes.

The basis for the following analysis is the establishment of a relationship between the strength of the extratropical zonal winds and temperature and precipitation, respectively. A measure for the strength of the zonal winds will be the South American Zonal Index (SAZI) as previously defined in the study of Wagner et al. (2007), representing the pressure difference between southern South America $\left(42^{\circ}-44^{\circ} \mathrm{S}\right.$; $\left.64^{\circ}-66^{\circ} \mathrm{W}\right)$ and the Antarctic Peninsula $\left(63^{\circ}-65^{\circ} \mathrm{S} ; 64^{\circ}-\right.$ $\left.66^{\circ} \mathrm{W}\right)$. The domain for each sub-region is based on $5 \times 5$ grid points selected from the interpolated SLP fields. Therefore, each region covers a $2^{\circ} \times 2^{\circ}$ degree domain in latitude and longitude. The grid points have been averaged over each sub-domain and the resulting values of the Antarctic Peninsula region have been subtracted from the South American sub-domain. The conceptual model describing the method- ological approach is included in the Appendix. In the following results based on this approach will be discussed.

The regression patterns together with the SAZI-induced temperature and precipitation changes are displayed in Figs. 8 and 9. Note that the analysis is performed separately for the PI and PD period, respectively, indicating different SAZI-induced climate changes depending on the period for which the regression coefficients have been estimated. Assuming that the statistical model implicitly includes physi$\mathrm{cal} /$ dynamical relationships between the extratropical zonal wind and the temperature/precipitation field, the lack of statistical significance should also indicate that these regions are not affected by changes in the extratropical winds. The physical foundation of the statistical model can, however, be supported by basic meteorological reasoning, for instance related to windward and leeward effects for precipitation in the proximity of the Andes Mountains over southern South America.

The regression patterns of temperature (Fig. 8) show positive regressions coefficients over the mid- and high latitudes, pronounced mostly over the eastern parts of southern South America south of $40^{\circ} \mathrm{S}$. However, these patterns show to some extent different structure depending on the period for which the regression coefficients have been estimated, i.e., the PI or PD period, respectively. For JJA for example, the statistically significant regression coefficients and, hence, the SAZI induced temperature changes, are more pronounced and extend further to the north over southern South America during PD. For DJF the statistically significant regression coefficients are not as widespread, especially over the continental areas, indicating that during austral summer the linear 


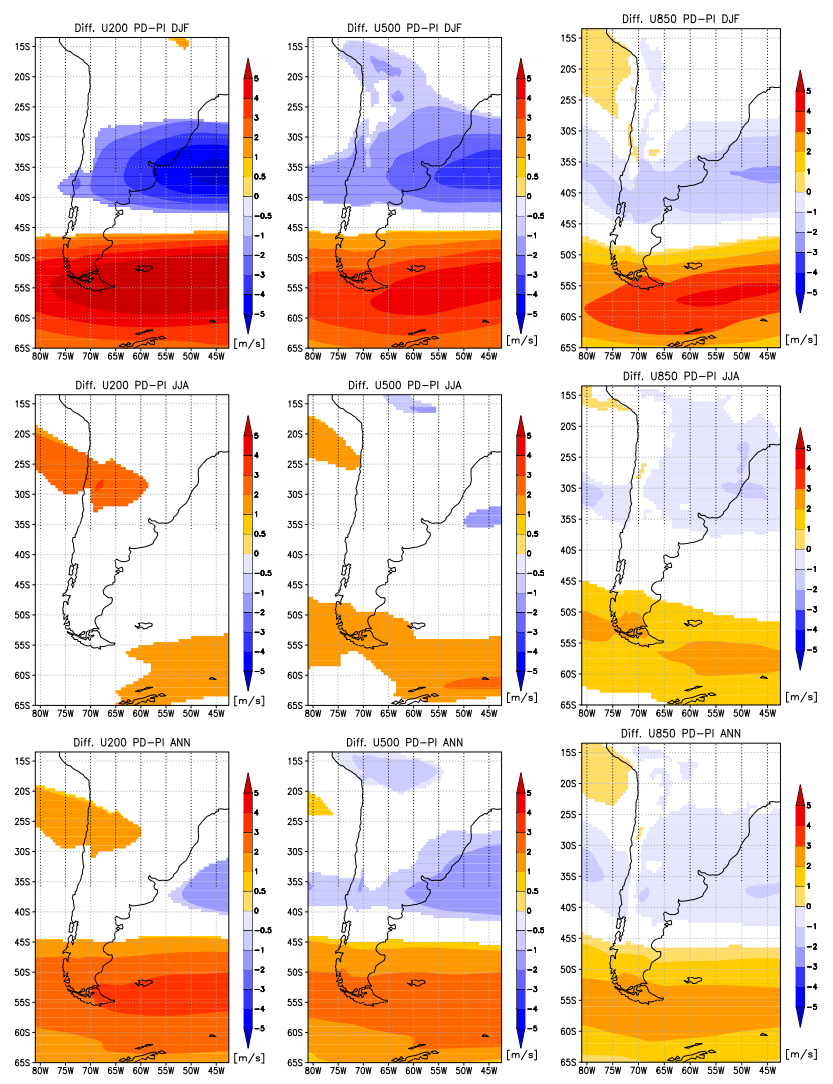

Fig. 7. Difference maps between the present-day and the preindustrial period for zonal winds for different atmospheric levels at $200 \mathrm{hPa}$ (left row), $500 \mathrm{hPa}$ (middle panel) and $850 \mathrm{hPa}$ (right row). Results are displayed for austral summer (December-February, left column), austral winter (June-August, middle column) and the annual mean (right column). Only values statistically significantly different at the $5 \%$ level are given (two-sided t-test).

relationship between SAZI and near-surface temperatures is not very strong.

The regression patterns of precipitation (Fig. 9) show a more heterogeneous structure over the tropical and subtropical latitudes. The region showing highest impact of the zonal winds on precipitation variability is located south of $35^{\circ} \mathrm{S}$ with a negative SAZI-precipitation relationship over the northern parts and a positive in the southern parts. For the subtropical regions the pattern is not very clear-cut and only few regions show statistically significant regression coefficients, indicating that precipitation variability of the tropical and subtropical regions of South America are not controlled to a large degree by changes in extratropical zonal winds. In the southernmost parts the rain-shadow effect of the Andes Mountains is indicated by the statistically significant negative regression coefficients over southeastern Patagonia. The southwestern parts of South America show positive regression coefficients indicating the advection effect of moist air masses from the Pacific Ocean onto the slopes of the An- des Mountains. The regression pattern vary depending on the season, thus, reflecting seasonal changes in the latitudinal position of the zonal winds.

For near-surface temperatures, the regression pattern between SAM/SAZI and near-surface temperatures obtained in the ECHO-G + CCLM simulations are similar to those presented in the studies of Gillet et al. (2006), Karpechko et al. (2009) and Garreaud et al. (2009) indicating positive regression coefficients over southern South America. For the PI pattern also the negative regression coefficients evident in the Gillet et al. (2006) and Garreaud et al. (2009) studies north of $40^{\circ} \mathrm{S}$ are evident.

For precipitation, the patterns are somewhat different. Over the south-western Andes Mountains the positive regression coefficients in the Karpechko et al. (2009) study are not as pronounced for the GPCP dataset as for the ECHO$\mathrm{G}+\mathrm{CCLM}$ simulation. The SAM-precipitation regression pattern displayed in the studies of Gillet et al. (2006) and Garreaud et al. (2009) also show similarities to the ECHO$\mathrm{G}+\mathrm{CCLM}$ regression patterns. The negative regression coefficients extending from central Chile into south-eastern Patagonia are reproduced by the regional model.

In contrast to the studies outlined above, the study of Garreaud (2007) uses the $300 \mathrm{hPa}$ and $700 \mathrm{hPa}$ zonal winds for estimating the point-by-point correlation with observational precipitation based on CMAP (Climate Prediction Center (CPC) Merged Analysis of Precipitation). The differences between SAZI-based and the $850 \mathrm{hPa}$ zonal wind grid-point based regression patterns for precipitation are mostly pronounced north of $45^{\circ} \mathrm{S}$, where the SAZI-based patterns show negative precipitation anomalies in conjunction with positive high-latitude zonal flow. In contrast, the zonal wind gridpoint based patterns shows positive precipitation anomalies along the entire South American coast in connection with increased zonal winds. The explanation for this discrepancy can be attributed to dynamical reasoning in relation to the impact of the SAM/SAZI on atmospheric circulation patterns: the regression/correlation pattern between the SAM/SAZI and SLP in the ECHO-G+CCLM simulation shows an increase in the pressure of the subtropical regions, mostly pronounced over the centres of the southeastern Pacific and south-western Atlantic anticyclones (not shown). For the south-eastern Pacific high pressure cell this implies an anomalous anticyclonic flow resulting in an increase in on-shore flow in regions south of approx $45^{\circ} \mathrm{S}$, but at the same time an increased off-shore flow in regions to the north of $45^{\circ} \mathrm{S}$. This results in a regression pattern with increased precipitation over south-western South America and reduced precipitation over central and northern Chile in the positive SAM/SAZI mode. Carrying out the regression/correlation analysis for zonal winds based on colocated grid points with precipitation does not imply this pattern-dependency, because every grid-point is treated individually for its precipitation-zonal wind relationship. Therefore, the grid-point analysis provides valuable information 

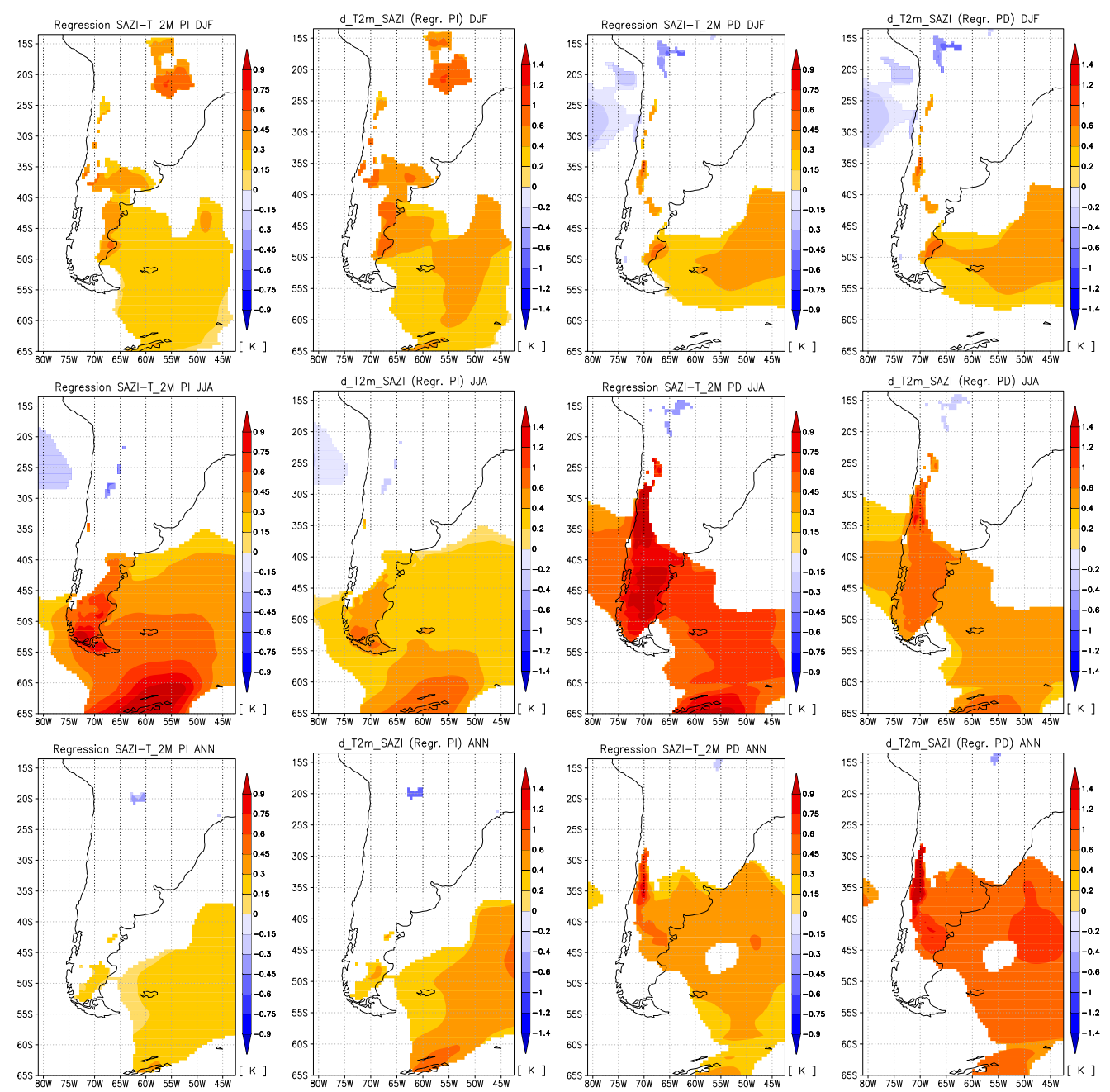

Fig. 8. Regression maps between SAZI and near-surface temperatures (1st and 3rd column) and temperature changes caused by SAZI differences between PD and PI (2nd and 4th column). Columns 1 and 2: regression based on pre-industrial period; columns 3 and 4: regression based on present-day period. Upper row: DJF; middle row: JJA; lower row: annual. Only statistically significant regression coefficients and related SAZI differences at the 5\% level are displayed.

on the relationship between zonal winds and precipitation in certain regions that might however be independent to the SAM/SAZI-precipitation relationship. This point has to be taken into account when comparing regression/correlation patterns based on different definitions on the regional expressions of zonal winds.

\subsection{Mechanisms}

To assess potential mechanisms explaining the differences between the PD and PI regression patterns, the near-surface wind circulation changes are further analysed (cf. Fig. 10). It becomes evident that not only changes in the zonal wind component are important but also changes in the meridional wind components. Most important in this respect are changes in the mean position and strength of the quasi-stationary circulation centres of the south-eastern Pacific and south- western Atlantic anticyclones. The basic pattern evident during the different seasons and the annual mean indicates that both centres show an intensification. For the western parts of South America this leads to a stronger zonal circulation in the southernmost parts, whereas regions to the north are affected by offshore winds. For eastern South America the anomalous south-westward advection of warm subtropical air masses into the continent also leads to an increase in SAZI-temperature regression during the PD period. For precipitation patterns the differences are not as clear-cut. Most wind-induced precipitation changes are indicated in the proximity of the Andes Mountains south of $35^{\circ} \mathrm{S}$. However, mean changes in the low level winds are reflected by the latitudinal shift of the zone with changes of the regression coefficients between the PD and PI periods along the western side of the 

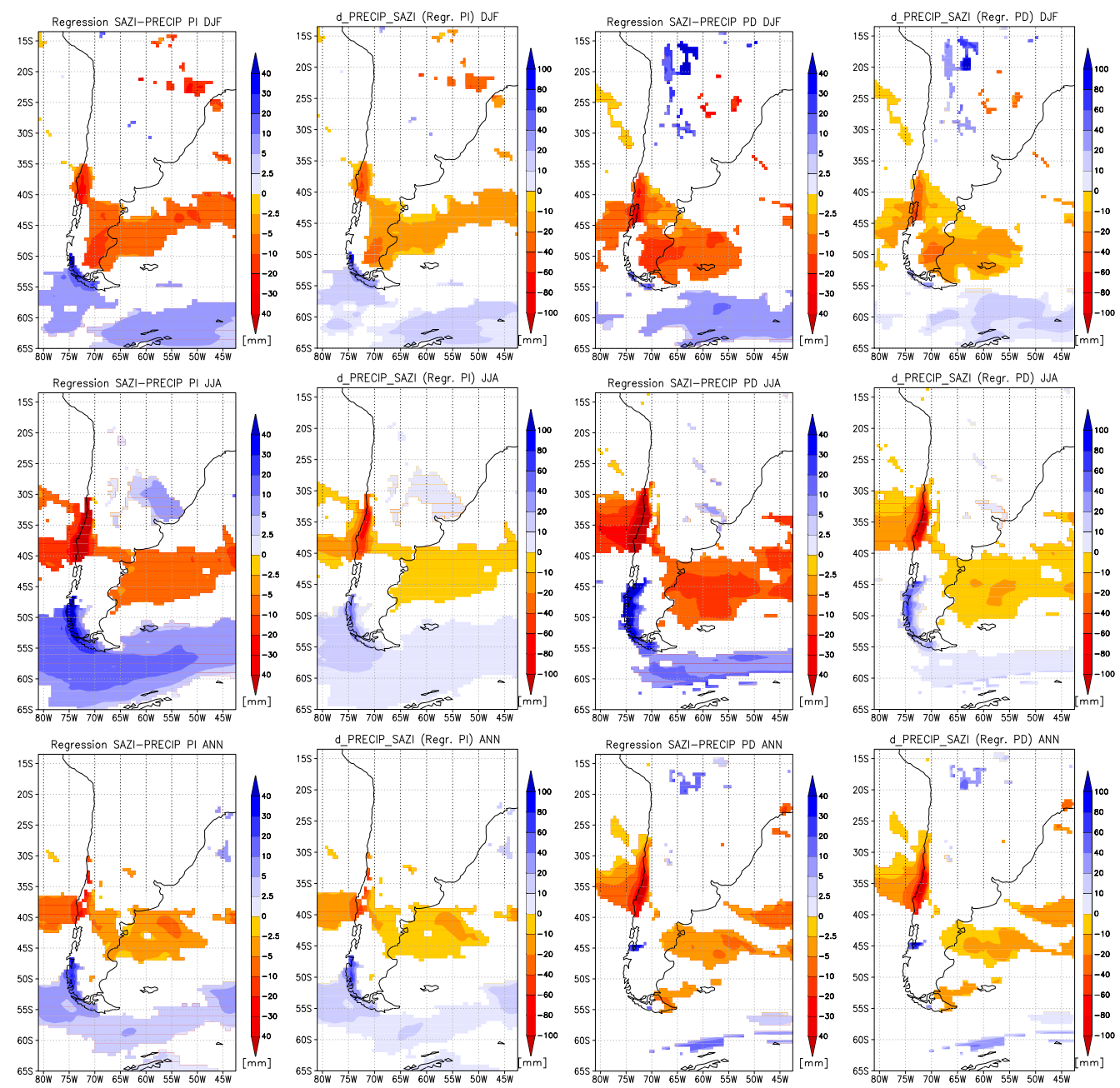

Fig. 9. Same as Fig. 8 except for precipitation.

Andes Mountains, for instance related to a northward shift of the statistically significant regression coefficients during JJA.

In addition to the fact that the regression patterns and the related SAZI-induced climatic change patterns show changes in the climate-circulation relationship, this result is also important for reconstructing climate indices based on statistical models constrained within the present-day climate. Although the analysis reveals that, especially for precipitation, the relationships are robust, mostly over the extratropics, changes in the SAZI-temperature regression patterns indicate that regionally changes might occur, depending on the period for which the regression coefficients have been estimated.

One should note, however, that model-specific biases might also have an influence on the spatial structure and amplitude of the regression patterns and the resulting SAZI-induced climatic changes. For instance, the annual temperature-SAZI regression pattern estimated for the PI period of (left column of Fig. 8) largely resembles the pattern given by Gillet et al. (2006), Garreaud et al. (2009) and Karpechko et al. (2009) obtained for observed 20th century climate. This indicates that, due to the increased zonal circulation of the driving ECHO-G model in the 20th century, the situation of PI times concerning the absolute strength of zonal winds is closer to observed 20th century conditions. In this light the situation for the modelled 20th century winds could potentially be seen as a future analogue in a climate with further increasing zonal winds. Additionally, one needs to consider that although the SAZI-induced climatic changes are formally constructed independently from other sources, they might also be influenced, via indirect effects related to deflections in the subtropical jet streams, through changes in the external greenhouse gas forcing. Therefore, the windinduced versus the radiation-induced climatic changes cannot be separated into independent processes.

\section{Discussion}

In light of the initially formulated hypotheses, changes in external forcing parameters related to an increase in $\mathrm{CO}_{2}$ 


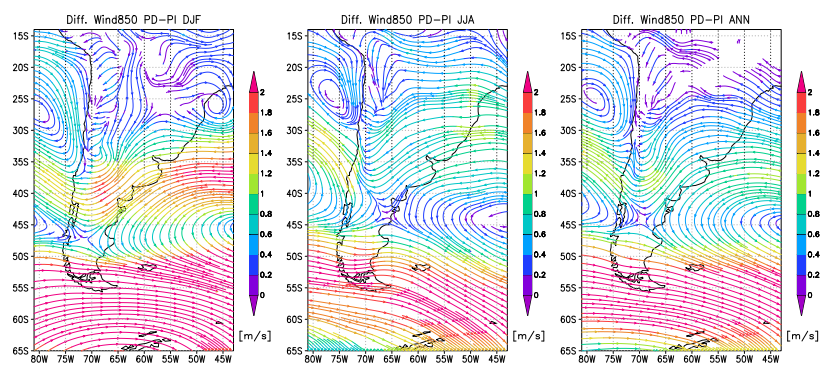

Fig. 10. Differences in Wind at $850 \mathrm{hPa}$ between present-day and pre-industrial times. Colours indicate differences in wind velocities. Left: DJF; middle: JJA; right: annual.

show a strong response of different climatic variables. Nearsurface temperatures show an increase in all latitudes, mostly pronounced over the Andes Mountains. This result is also consistent with studies carried out earlier for future climate studies in the context of changes in greenhouse gas concentrations (Christensen et al., 2007), although the temperature increase is mostly pronounced more to the north over the Amazonian basin. In the context of proxy reconstructions model results are also in qualitative agreement, even though the model seems to overestimate the temperature response between the PD and the PI climate (cf. Neukom et al., 2010a; Villalba et al., 2003). The temperature increase is, however, also supported by further temperature-sensitive proxy data, indicating cooler temperatures over most of the preindustrial period in conjunction with the period of the Little Ice Age (LIA) (e.g., Koch and Killian, 2005; von Gunten et al., 2009) and related glacial advances (cf. Vimeux et al., 2009; Makiokas et al., 2009). For precipitation changes the comparison between model and reconstructions is more difficult to evaluate because of the more heterogeneous precipitation patterns and processes involved as well as the larger uncertainties contained in both approaches. Regions showing qualitative agreements are related to southern Patagonia during summer (Neukom et al., 2010b) and the decrease in precipitation over central Chile in the course of the 20th century (Christie et al., 2010). However, other records (Piovano et al., 2002; Boninsegna, 1995), show a different situation with drier conditions during the 17 th and 18th century over the more equatorward regions. It should, however, be noted that the comparison between the model results and proxy data is hampered by the fact that simulations are carried out as quasi-equilibrium simulations without any varying external forcing factors. For a better basis for comparisons transient simulations forced with changes in external forcings should be taken into account. Moreover, model biases involved in the global and regional climate model might also influence the amount of the differences between climatic periods. For instance, given the mean climatic conditions are not simulated well enough by the models also the difference pattern might be biased.
The disagreement between model and reconstructions might also be partly explained by the strong zonal circulation in the driving ECHO-G model producing a different PD climate-circulationship pattern that in turn results in a re-enforcement of the temperature response caused by dynamical forcing mechanisms. As already noted, especially the regression pattern between temperature and near-surface westerly winds obtained in the PI period, is closer to the one based on observations (Gillet et al., 2006; Garreaud et al., 2009) compared to the pattern based on the PD period. An important mechanism potentially explaining the differences seems to be the strengthening of the South Atlantic subtropical high pressure cell leading to an increased advection of warm subtropical air into the South American continent (cf. Silvestri and Vera, 2009). Over the south-eastern Pacific the increase of the South Pacific anticyclone leads to an anomalous south-easterly flow north of $50^{\circ} \mathrm{S}$. This increase in sea level pressure weakens the advection of moist air masses from the Pacific Ocean onto the slopes of the Andes Mountains leading to lower precipitation. Over the higher latitudes the process of polar amplification suggested for the Northern Hemisphere (Holland and Bitz, 2003; Serreze and Francis, 2006) is most likely alleviated by increased Ekman pumping in the southern Ocean caused by increases in zonal winds. As already noted above, this Ekman pumping might, however, be overestimated in the global climate model and, hence, the damping effect of this process might not be as large in the real world compared to the model. However, regions further south such as the Antarctic Peninsula, show a more prominent warming compared to the oceanic sites to the north, also consistent with observations (Vaughan et al., 2003).

Precipitation changes are also influenced by changes in the climate-circulation relationship between PD and PI. In contrast to temperatures mostly the regions to the south of $35^{\circ} \mathrm{S}$ show wind-induced precipitation changes. The region indicating a change between negative and positive wind-induced precipitation regression coefficients remains similar during both periods, except for austral summer when changes in mean atmospheric circulation are mostly pronounced. A notable finding indicated by the regional simulations relates to the fact that despite the quite homogenous pattern for the temperature changes, differences related to hydrological variables show a much more local-scale pattern. This point is of specific interest for reconstructing climate indices based on empirical evidence. Results based on the regional climate simulations suggest that it is of ultimate importance (i) to establish transfer functions based on seasonal rather than annual averages and (ii) to take into consideration potential influences of the calibration period used for statistically based reconstruction approaches.

The added value of the regional climate model simulation over the global simulation is mostly related to hydrological variables, for instance precipitation. Due to the more realistic representation of the structure and complexity of the Andes Mountains, effects related to the uplift of air masses and 
related precipitation processes are reproduced better within the regional model simulation. Also the rain-shadow effect caused by the Andes Mountains can be resolved with the help of the higher resolved regional climate model in greater detail. Another point also relates to the parameterisation of precipitation that can be improved using regional climate models.

\section{Summary}

In the present study, two simulations with the regional climate model CCLM have been investigated for climatic changes between present-day and pre-industrial times. The regional model was integrated on a $0.44^{\circ} \times 0.44^{\circ}$ grid resolution and was forced with global simulations of the ECHO-G model with a horizontal resolution of $3.75^{\circ} \times 3.75^{\circ}$.

Some spatial model biases are evident, for instance related to an overestimation of temperatures in the ECHO$\mathrm{G}+\mathrm{CCLM}$ simulation in large parts over eastern and central South America in conjunction with a negative precipitation bias in these regions. This bias might be related to simulated SLP that is too high compared to observational data. In the southernmost parts a negative temperature bias in conjunction with positive precipitation biases is simulated by the present-day ECHO-G + CCLM simulation. These biases can, in turn, partly be explained by sea-level pressure biases over these areas that are too low, leading to an increased westerly flow. Besides these factors also other processes related to specific soil conditions and land-cover could explain part of the precipitation biases especially during the austral summer. Moreover, explaining precipitation biases based on model results also needs to take into account the specific model setup and parameterisations.

The main findings of the study can, thus, be summarised as follows:

- The regional climate model CCLM is able to capture the mean climatological features related to temperature and precipitation for the climatological (here $5 \mathrm{yr}$ driven with ERA40) mean and the annual cycle, albeit that temperatures show a cold bias. The comparison between the ECHO-G + CCLM simulation for the 20th century and observations also shows model biases different to those obtained for the ERA40-driven simulations, pointing to the importance of validating separately the regional climate model for re-analysis and GCM-driven simulations, respectively.

- Near-surface temperatures between present-day and pre-industrial times show positive temperature anomalies over most regions over southern and central South America in the order of $1-1.5 \mathrm{~K}$, and up to $2 \mathrm{~K}$ over the Andes Mountains.

- Precipitation differences show a more heterogeneous pattern with highest differences along the western side of the Andes Mountains in conjunction with a dipole pattern indicating reduced precipitation in the northern parts and increased precipitation in the southern parts of southern South America during PD.

In the present study, results of only one regional model have been discussed. As for the global models it could also be expected for regional models to show different responses even when the same GCM forcing is applied. This might, for instance, be caused by different convection schemes or different land surface models employed in the respective regional model. Another important point related to the comparison between the results obtained for the regional model and proxy data is to use regional climate model simulations forced with changes in varying external forcing factors in order to take into account decadal and multi-decadal climate variability. Even though these points are demanding, they should at least be addressed to assess the bandwidth of natural and anthropogenically forced climatic variability from a modelling perspective.

\section{Appendix A}

\section{Statistical model for estimation of wind-related climatic changes}

Formally, our conceptual model explaining temperature and precipitation changes of present-day and pre-industrial times consists of two components, the first related to wind-driven changes and a second, i.e., the residual, including other sources, most likely changes induced by direct radiative forcing. The equations given below are for the case of temperature, but also apply for precipitation changes:

$\Delta T_{\mathrm{tot}}=\Delta T_{\mathrm{SAZI}}+\Delta T_{\mathrm{res}}$

with $\Delta T_{\text {tot }}$ representing the total temperature difference PD minus PI, $\Delta T_{\text {SAZI }}$ being the temperature difference caused by changes in zonal winds and $\Delta T_{\text {res }}$ being the temperature changes independent to wind-induced changes, e.g., caused by changes in direct radiation. We use the following linear statistical model estimating the effect of the wind strength of temperature and precipitation changes:

$T(t)=\alpha_{0}+\alpha_{1} \cdot \operatorname{SAZI}(t)+\alpha(t)$

with $T(t)$ representing the seasonal temperature evolution (30 yr), $\alpha_{1}$ representing the regression coefficient linking changes in $T(t)$ with changes in zonal winds ( $\operatorname{SAZI}(t))$. $\alpha(t)$ indicate the residuals that cannot be linearly explained by changes in zonal winds. $\alpha_{0}$ is zero because we use (detrended) anomalies when estimating the regression coefficients. Note that the calculation of the SAZI-climate regression maps is based on the normalised SAZI values. The mean SAZI difference between the PD and PI period is used to estimate the effect of the westerly winds on temperature and 
precipitation:

$$
\Delta T_{\mathrm{SAZI}}=\Delta \mathrm{SAZI} \mathrm{PD-PI} \cdot \alpha_{1}
$$

i.e., the regression coefficients are multiplied with the mean SAZI difference between PD and PI times for the different seasons and the annual mean. Here it has been taken care that the regression coefficients of the non-normalised SAZI values in units of $\mathrm{K} \mathrm{hPa}^{-1}$ and $\mathrm{mm} \mathrm{hPa}{ }^{-1}$ have been used, respectively. The mean SAZI difference $\triangle$ SAZI PD-PI $_{\text {PI }}$ between $\mathrm{PD}$ and $\mathrm{PI}$ is $+6.37 \mathrm{hPa}$ (DJF), $+4.52 \mathrm{hPa}$ (JJA) and $+4.97 \mathrm{hPa}$ (ANN), respectively.

Acknowledgements. The simulations have been carried out in the framework of the project "Regional climate modelling in southern South America for the Holocene and the 21st century - REGCLIMOSS" funded by the German Research foundation. The regional climate model simulations have been carried out on a NEC-SX6 at the German Climate Computing Center. We thank the four anonymous reviewers for their very helpful and valuable comments on earlier versions of the manuscript.

Edited by: T. Kiefer

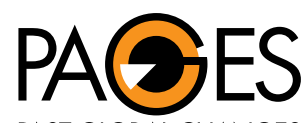

The publication of this article was sponsored by PAGES.

PAST GLOBAL CHANGES

\section{References}

Anders, I. and Rockel, B.: The influence of prescribed soil type distribution on the representation of present climate in a regional climate model, Clim. Dynam., 33, 177-186, doi:10.1007/s00382008-0470-y, 2009.

Bals-Elsholz, T. M., Atallah, E. H., Bosart, L. F., Wasula, T. A., Cempa, M. J., and Lupo, A. R.: The wintertime Southern Hemisphere split jet: Structure, variability, and evolution, J. Climate, 14, 4191-4215, 2001.

Böhm, U., Gerstengarbe, F.-W., Hauffe, D., Kücken, M., Österle, H., and Werner, P. C.: Dynamic regional climate modeling and sensitivity experiments for the northeast of Brazil, in: Global Change and Regional Impacts, edited by: Gaiser, T., Krol, M., Frischkorn, H., and Araújo, J. C., Springer-Verlag Berlin Heidelberg New York, 153-170, 2003.

Boninsegna, J. A.: South American dendrochronological records, in: Climate since A.D. 1500, edited by: Bradley, R. S. and Jones, P. D., Routledge, London, 1995.

Boucher, É., Guiot, J., and Chapron, E.: A millennial multi-proxy reconstruction of summer PDSI for Southern South America, Clim. Past, 7, 957-974, doi:10.5194/cp-7-957-2011, 2011.

Cai, W. and Cowan, T.: Trends in Southern Hemisphere Circulation in IPCC AR4 Models over 1950-99: Ozone Depletion versus Greenhouse Forcing, J. Climate, 20, 681-693, doi:10.1175/JCLI4028.1, 2007.

Carvalho, L. M. V., Jones, C., and Liebmann, B.: The South Atlantic Convergence Zone: Intensity, Form, Persistence, and Rela- tionships with Intraseasonal to Interannual Activity and Extreme Rainfall, J. Climate, 17, 88-108, 2004.

Christensen, J. H., Hewitson, B., Busuioc, A., Chen, A., Gao, X., Held, I., Jones, R., Kolli, R. K., Kwon, W.-T., Laprise, R., Magaña Rueda, V., Mearns, L., Menéndez, C. G., Räisänen, J., Rinke, A., Sarr, A., and Whetton, P.: Regional Climate Projections, in: Climate Change 2007: The Physical Science Basis, Contribution of Working Group I to the Fourth Assessment Report of the Intergovernmental Panel on Climate Change, edited by: Solomon, S., Qin, D., Manning, M., Chen, Z., Marquis, M., Averyt, K. B., Tignor, M., and Miller, H. L., Cambridge University Press, Cambridge, United Kingdom and New York, NY, USA, 2007.

Christie, D., Boninsegna, J., Cleaveland, M., Lara, A., Le Quesne, C., Morales, M., Mudelsee, M., Stahle, D., and Villalba, R.: Aridity changes in the Temperate-Mediterranean transition of the Andes since AD 1346 reconstructed from tree-rings, Clim. Dynam., 36, 1505-1521, doi:10.1007/s00382-009-0723-4, 2010.

Garreaud, R. D.: Precipitation and Circulation Covariability in the Extratropics, J. Climate, 20, 4789-4797, doi:10.1175/JCLI4257.1, 2007.

Garreaud, R. D., Vuille, M., Compagnucci, R., and Marengo, J.: Present day South American climate, Palaeogeogr. Palaeocl., 281, 180-195, doi:10.1016/j.palaeo.2007.10.032, 2009.

Gillett, N. P., Kell, T. D., and Jones, P. D.: Regional climate impacts of the Southern Annular Mode, Geophys. Res. Lett., 33, L23704, doi:10.1029/2006GL027721, 2006.

Haberzettl, T., Fey, M., Lücke, A., Maidana, N., Mayr, C., Ohlendorf, C., Schäbitz, F., Schleser, G. H., Wille, M., and Zolitschka, B.: Climatically induced lake level changes during the last two millennia as reconstructed in sediments of Laguna Potrok Aike, southern Patagonia (Santa Cruz, Argentina), J. Paleolimnol., 33, 283-302, doi:10.1007/s10933-004-5331-z, 2005.

Hall, A. and Visbeck, M.: Synchronous Variability in the Southern Hemisphere Atmosphere, Sea Ice, and Ocean Resulting from the Annular Mode, J. Climate, 15, 3043-3057, 2002.

Holland, M. M. and Bitz, C. M.: Polar amplification of climate change in the Coupled Model Intercomparison Project, Clim. Dynam., 21, 221-232, 2003.

Jaeger, E. B., Anders, I., Lüthi, D., Rockel, B., Schär, C., and Seneviratne, S. I.: Analysis of ERA40-driven CLM simulations for Europe, Meteorol. Z., 17, 349-368, 2008.

Karpechko, A. Y., Gillett, N. P., Marshall, G. J., and Screen, J. A.: Climate Impacts of the Southern Annular Mode Simulated by the CMIP3 Models, J. Climate, 22, 3751-3768, doi:10.1175/2009JCLI2788.1, 2009.

Kistler, R., Kalnay, E., Collins, W., Saha, S., White, G., Woollen, J., Chelliah, M., Ebisuzaki, W., Kanamitsu, M., Kousky, V., van den Dool, H., Jenne, R., and Fiorino, M.: The NCEP/NCAR 50-year reanalysis: monthly means CD ROM and documentation, B. Am. Meteorol. Soc., 822, 47-267, 2001.

Koch, J. and Kilian, R.: "Little Ice Age" glacier fluctuations, Gran Campo Nevado, southernmost Chile, Holocene, 15, 20-28, 2005.

Lamy, F., Hebbeln, D., Röhl, U., and Wefer, G.: Holocene rainfall variability in southern Chile: a marine record of latitudinal shifts of the Southern Westerlies, Earth Planet. Sc. Lett., 185, 369-382, 2001.

Lamy, F., Kilian, R., Arz, H. W., Francois, J. P., Kaiser, J., Prange, M., and Steinke, T.: Holocene changes in the position and 
intensity of the southern westerly wind belt, Nat. Geosci., 3, 695699, doi:10.1038/NGEO959, 2010.

Legutke, S. and Voss, R.: The Hamburg atmosphere-ocean coupled model ECHO-G, Tech. Rep. 18, German Climate Computer Center (DKRZ), available at: www.mad.zmaw.de/fileadmin/ extern/documents/reports/ReportNo.18.pdf (last access: 11 October 2012), 1999.

Markgraf, V., Bradbury, J., Schwalb, A., Burns, S., Stern, C., Ariztegui, D., Anselmetti, F., Stine, S., and Maidana, N.: Holocene palaeoclimates of southern Patagonia: limnological and environmental history of Lago Cardiel, Argentina, Holocene, 13, 581-591, 2003.

Marshall, G. J., Stott, P. A., Turner, J., Connolley, W. M., King, J. C., and Lachlan-Cope, T. A.: Causes of exceptional atmospheric circulation changes in the Southern Hemisphere, Geophys. Res. Lett., 31, L14205, doi:10.1029/2004GL019952, 2004.

Masiokas, M. H., Rivera, A., Espizua, L. E., Villalba, R., Delgado, S., and Aravena, J. C.: Glacier fluctuations in extratropical South America during the past 1000 years, Palaeogeogr. Palaeoecl., 281, 242-268, doi:10.1016/j.palaeo.2009.08.006, 2009.

Masson, V., Champeaux, J.-L., Chauvin, F., Meriguet, C., and Lacaze, R.: A global database of land surface parameters at 1-km resolution in meteorological and climate models, J. Climate, 16, 1261-1282, 2003.

Mayr, C., Fey, M., Haberzettl, T., Janssen, S., Lücke, A., Maidana, N., Ohlendorf, C., Schäbitz, F., Schleser, G., Struck, U., Wille, M., and Zolitschka, B.: Palaeoenvironmental changes in southern Patagonia during the last millennium recorded in lake sediments from Laguna Azul (Argentina), Palaeogeogr. Palaeoecol., 228, 203-227, doi:10.1016/j.palaeo.2005.06.001, 2005.

Meyer, I. and Wagner, S.: The Little Ice Age in Southern South America: Proxy and Model Based Evidence, in: Past Climate Variability in South America and Surrounding Regions, Developments in Paleoenvironmental Research, edited by: Vimeux, F., Sylvestre, F., and Khodri, M., 14, 395-412, doi:10.1007/978-90481-2672-9_16, 2009.

Min, S.-K., Legutke, S., Hense, A., and Kwon, W.-T.: Internal variability in a 1000-year control simulation with the coupled climate model ECHO-G - I. Near-surface temperature, precipitation and mean sea-level pressure, Tellus A, 57, 605-621, 2005.

Mitchell, T. D. and Jones, P. D.: An improved method of constructing a database of monthly climate observations and associated high-resolution grids, Int. J. Climatol., 25, 693-712, 2005.

Moreno, P., François, J. P., Villa-Martínez, R. P., and Moy, C. M.: Millennial-scale variability in Southern Hemisphere westerly wind activity over the last 5,000 years in SW Patagonia, Quaternary Sci. Rev., 28, 25-38, doi:10.1016/j.quascirev.2008.10.009, 2009.

Nakamura, H., Sampe, T., Goto, A., Ohfuchi, W., and Xie, S.-P.: On the importance of midlatitude oceanic frontal zones for the mean state and dominant variability in the tropospheric circulation, Geophys. Res. Lett., 35, L15709, doi:10.1029/2008GL034010, 2008.

Neukom, R., Luterbacher, J., Villalba, R., Küttel, M., Frank, D., Jones, P. D., Grosjean, M., Wanner, H., Aravena, J. C., Black, D. E., Christie, D. A., D’Arrigo, R., Lara, A., Morales, M., SolizGamboa, C., Srur, A., Urrutia, R., and von Gunten, L.: Multiproxy summer and winter surface air temperature field reconstructions for southern South America covering the past cen- turies, Clim. Dynam., 37, 35-51, doi:10.1007/s00382-010-07933, 2010a.

Neukom, R., Luterbacher, J., Villalba, R., Küttel, M., Frank, D., Jones, P. D., Grosjean, M., Esper, J., Lopez, L., and Wanner, H.: Multi-centennial summer and winter precipitation variability in southern South America, Geophys. Res. Lett., 37, L14708, doi:10.1029/2010GL043680, 2010b.

Piovano, E. L., Ariztegui, D., and Damatto Moreiras, S.: Recent environmental changes in Laguna Mar Chiquita (central Argentina): a sedimentary model for a highly variable saline lake, Sedimentology, 49, 1371-1384, 2002.

Rockel, B. and Geyer, B.: The performance of the regional climate model CLM in different climate regions, based on the example of precipitation, Meteorol. Z., 17, 487-498, 2008.

Roeckner, E., Arpe, K., Bengtsson, L., Christoph, M., Claussen, M., Dümenil, L., Esch, M., Giorgetta, M., Schlese, U., and Schulzweida, U.: The atmospheric general circulation model ECHAM4: model description and simulation of present-day climate, Tech. Rep. 218, Max Planck Institut für Meteorologie, 1996.

Rudolf, B., Becker, A., Schneider, U., Meyer-Christoffer, A., and Ziese, M.: GPCC Status Report, Global Precipitation Climatology Center, available at: http://gpcc.dwd.de (last access: 11 October 2012), 2010.

Salio, P., Nicolini, M., and Saulo, A. C.: Chaco low-level jet events characterization during the austral summer season, J. Geophys. Res., 107, 4816, doi:10.1029/2001JD001315, 2002.

Schäbitz, F.: PaläoökologischeUntersuchungen an geschlossenen Hohlformen in den Trockengebieten Patagoniens, Tech. Rep. 17, Universität Bamberg, 1999.

Screen, J. A., Gillett, N. P., Karpechko, A. Y., and Stevens, D. P.: Mixed Layer Temperature Response to the Southern Annular Mode: Mechanisms and Model Representation, J. Climate, 23, 664-678, doi:10.1175/2009JCLI2976.1, 2010.

Seager, R., Naik, N., Baethgen, W., Robertson, A., Kushnir, Y., Nakamura, J., and Jurburg, S.: Tropical Oceanic Causes of Interannual to Multidecadal Precipitation Variability in Southeast South America over the Past Century, J. Climate, 23, 5517-5539, doi:10.1175/2010JCLI3578.1, 2010.

Sen Gupta, A. and England, M.: Coupled ocean-atmosphere-ice response to variations in the Southern Annular Mode, J. Climate, 19, 4457-4486, doi:10.1175/JCLI3843.1, 2006.

Serreze, M. C. and Francis, J. A.: The Arctic amplification debate, Climatic Change, 76, 241-264, doi:10.1007/s10584-005-9017-y, 2006.

Silvestri, G. and Vera, C.: Nonstationary impacts of the Southern Annular Mode on Southern Hemisphere climate, J. Climate, 22, 6142-6148, doi:10.1175/2009JCLI3036.1, 2009.

Silvestri, G., Vera, C., Jacob, D., Pfeifer, S., and Teichmann, C.: A high resolution 43-year atmospheric hindcast for South America generated with the MPI regional model, Clim. Dynam., 32, 693 709, 2009.

Smiatek, G., Rockel, B., and Schättler, U.: Time invariant data preprocessor for the climate version of the COSMO model (COSMO-CLM), Meteorol. Z., 17, 395-405, doi:10.1127/09412948/2008/0302, 2008.

Solman, S., Nuñez, M., and Cabré, M. F.: Regional climate change experiments over southern South America. I: present climate, Clim. Dynam., 30, 533-552, doi:10.1007/s00382-007-0304-3, 
2008.

Thompson, D. and Wallace, J.: Annular Modes in the Extratropical Circulation. Part I: Month to Month Variability, J. Climate, 13, 1000-1016, 2000.

Thompson, D., Wallace, J., and Hegerl, G.: Annular Modes in the Extratropical Circulation. Part II: Trends, J. Climate, 13, 10181036, 2000.

Uppala, S. M., Kållberg, P. W., Simmons, A. J., Andrae, U., Bechtold, V., Da Costa, Fiorino, M., Gibson, J. K., Haseler, J., Hernandez, A., Kelly, G. A., Li, X., Onogi, K., Saarinen, S., Sokka, N., Allan, R. P., Andersson, E., Arpe, K., Balmaseda, M. A., Beljaars, A. C. M., Bidlot, J., Bormann, N., Caires, S., Chevallier, F., Dethof, A., Dragosavac, M., Fisher, M., Fuentes, M., Hagemann, S., Hólm, E., Hoskins, B. J., Isaksen, L., Janssen, P. A. E. M., Jenne, R., McNally, A. P., Mahfouf, J.-F., Morcrette, J.-J., Rayner, N. A., Saunders, R. W., Simon, P., Sterl, A., Trenberth, K. E., Untch, A., Van de Berg, L., Vasiljevic, D., Viterbo, P., and Woollen, J.: The ERA-40 re-analysis, Q. J. Roy. Meteorol. Soc., 131, 2961-3012, doi:10.1256/qj.04.176, 2005.

Vaughan, D. G., Marshall, G. J., Connolley, W. M., Parkinson, C. L., Mulvaney, R., Hodgson, D. A., King, J. C., Pudsey, C. J., and Turner, J.: Recent rapid regional climate warming on the Antarctic Peninsula, Climatic Change, 60, 243-274, 2003.

Vera, C., Higgins, W., Amador, J., Ambrizzi, T., Garreaud, R., Gochis, D., Gutzler, D., Lettenmaier, D., Marengo, J., Mechoso, C. R., Nogues-Paegle, J., Dias, P. L. S., and Zhang, C.: Toward a unified view of the American Monsoon Systems, J. Climate, 19, 4977-5000, doi:10.1175/JCLI3896.1, 2006a.

Vera, C., Baez, J., Douglas, M., Emmanuel, C. B., Marengo, J., Meitin, J., Nicolini, M., Nogues-Paegle, J., Paegle, J., Penalba, O., Salio, P., Saulo, C., Silva Dias, M. A., Silva Dias, P., and Zipser, E.: The South American Low-Level Jet Experiment, B. Am. Meteorol. Soc., 87, 63-77, 2006 b.

Vera, C., Silvestri, G., Liebmann, B., and González, P.: Climate change scenarios for seasonal precipitation in South America from IPCC-AR4 models, Geophys. Res. Lett., 33, L13707, doi:10.1029/2006GL025759, 2006c.

Villa-Martínez, R. and Moreno, P. I.: Pollen evidence for variations in the southern margin of the westerly winds in SW Patagonia over the last 12,600 years, Quaternary Res., 68, 400-409, doi:10.1016/j.yqres.2007.07.003, 2007.
Villalba, R., Lara, A., Boninsegna, J. A., Masiokas, M., Delgado, S., Aravena, J. C., Roig, F. A., Schmelter, A., Wolodarsky, A., and Ripalta, A.: Large-scale temperature changes across the southern Andes: 20th-century variations in the context of the past 400 years, Climatic Change, 59, 177-232, 2003.

Vimeux, F., Ginot, P., Schwikowski, M., Vuille, M., Hoffmann, G., Thompson, L. G., and Schotterer, U.: Climate variability during the last 1000 years inferred from Andean ice cores: A review of methodology and recent results, Palaeogeogr. Palaeocl., 281, 229-241, doi:10.1016/j.palaeo.2008.03.054, 2009.

von Gunten, L., Grosjean, M., Rein, B., Urrutia, R., and Appleby, P.: A quantitative high-resolution summer temperature reconstruction based on sedimentary pigments from Laguna Aculeo, central Chile, back to AD 850, Holocene, 19, 873-881, doi:10.1177/0959683609336573, 2009.

Wagner, S., Widmann, M., Jones, J., Haberzettl, T., Lücke, A., Mayr, C., Ohlendorf, C., Schäbitz, F., and Zolitschka, B.: Transient simulations, empirical reconstructions and forcing mechanisms for the Mid-Holocene hydrological climate in Southern Patagonia, Clim. Dynam., 29, 333-355, doi:10.1007/s00382007-0229-x, 2007.

Wilmes, S. B., Raible, C. C., and Stocker, T. F.: Climate variability of the mid- and high-latitudes of the Southern Hemisphere in ensemble simulations from 1500 to 2000 AD, Clim. Past, 8, 373390, doi:10.5194/cp-8-373-2012, 2012.

Wolff, J., Maier-Reimer, E., and Legutke, S.: The Hamburg Primitive Equation Model HOPE, Tech. Rep. 18, German Climate Computer Center (DKRZ), 1997.

Wu, L., Cai, W., Zhang, L., Nakamura, H., Timmermann, A., Joyce, T., McPhaden, M. J., Alexander, M., Qiu, B., Visbeck, M., Chang, P., and Giese, B.: Enhanced warming over the global subtropical western boundary currents, Nat. Clim. Cha., 2, 161-166, doi:10.1038/nclimate1353, 2012.

Yang, X.-Y., Wang, D., Wang, J., and Huang, R. X.: Connection between the decadal variability in the Southern Ocean circulation and the Southern Annular Mode, Geophys. Res. Lett., 34, L16604, doi:10.1029/2007GL030526, 2007. 